\title{
Direct linking of Greenland and Antarctic ice cores at the Toba eruption (74 ka BP)
}

\author{
A. Svensson ${ }^{1}$, M. Bigler ${ }^{2}$, T. Blunier ${ }^{1}$, H. B. Clausen ${ }^{1}$, D. Dahl-Jensen ${ }^{1}$, H. Fischer ${ }^{2}$, S. Fujita ${ }^{3}$, K. Goto-Azuma ${ }^{3}$, \\ S. J. Johnsen ${ }^{1}$, K. Kawamura ${ }^{3}$, S. Kipfstuhl ${ }^{4}$, M. Kohno ${ }^{5}$, F. Parrenin ${ }^{6,7}$, T. Popp ${ }^{1}$, S. O. Rasmussen ${ }^{1}$, J. Schwander ${ }^{2}$, \\ I. Seierstad ${ }^{1}$, M. Severi ${ }^{8}$, J. P. Steffensen ${ }^{1}$, R. Udisti ${ }^{8}$, R. Uemura ${ }^{9}$, P. Vallelonga ${ }^{1}$, B. M. Vinther ${ }^{1}$, A. Wegner ${ }^{4}$, \\ F. Wilhelms ${ }^{4}$, and M. Winstrup ${ }^{1}$ \\ ${ }^{1}$ Centre for Ice and Climate, Niels Bohr Institute, University of Copenhagen, Denmark \\ ${ }^{2}$ Climate and Environmental Physics, Physics Institute \& Oeschger Centre for Climate Change Research, University of Bern, \\ Bern, Switzerland \\ ${ }^{3}$ National Institute of Polar Research, Tachikawa, Tokyo, Japan \\ ${ }^{4}$ Stiftung Alfred-Wegener-Institut für Polar- und Meeresforschung, Bremerhaven, Germany \\ ${ }^{5}$ Geoscience Center, University of Göttingen, Göttingen, Germany \\ ${ }^{6}$ Laboratoire Chrono-environnement, Besancon, France \\ ${ }^{7}$ Laboratoire de Glaciologie et Geophysique de l'Environnement, Grenoble, France \\ ${ }^{8}$ Department of Chemistry "Ugo Schiff", University of Florence, Florence, Italy \\ ${ }^{9}$ Department of Chemistry, Biology, and Marine Science, University of the Ryukyus, Okinawa, Japan
}

Correspondence to: A. Svensson (as@gfy.ku.dk)

Received: 24 September 2012 - Published in Clim. Past Discuss.: 5 November 2012

Revised: 6 March 2013 - Accepted: 6 March 2013 - Published: 19 March 2013

\begin{abstract}
The Toba eruption that occurred some 74 ka ago in Sumatra, Indonesia, is among the largest volcanic events on Earth over the last 2 million years. Tephra from this eruption has been spread over vast areas in Asia, where it constitutes a major time marker close to the Marine Isotope Stage 4/5 boundary. As yet, no tephra associated with Toba has been identified in Greenland or Antarctic ice cores. Based on new accurate dating of Toba tephra and on accurately dated European stalagmites, the Toba event is known to occur between the onsets of Greenland interstadials (GI) 19 and 20. Furthermore, the existing linking of Greenland and Antarctic ice cores by gas records and by the bipolar seesaw hypothesis suggests that the Antarctic counterpart is situated between Antarctic Isotope Maxima (AIM) 19 and 20.

In this work we suggest a direct synchronization of Greenland (NGRIP) and Antarctic (EDML) ice cores at the Toba eruption based on matching of a pattern of bipolar volcanic spikes. Annual layer counting between volcanic spikes in both cores allows for a unique match. We first demonstrate this bipolar matching technique at the already synchronized Laschamp geomagnetic excursion (41 ka BP) before
\end{abstract}

we apply it to the suggested Toba interval. The Toba synchronization pattern covers some $2000 \mathrm{yr}$ in GI-20 and AIM$19 / 20$ and includes nine acidity peaks that are recognized in both ice cores.

The suggested bipolar Toba synchronization has decadal precision. It thus allows a determination of the exact phasing of inter-hemispheric climate in a time interval of poorly constrained ice core records, and it allows for a discussion of the climatic impact of the Toba eruption in a global perspective. The bipolar linking gives no support for a long-term global cooling caused by the Toba eruption as Antarctica experiences a major warming shortly after the event. Furthermore, our bipolar match provides a way to place palaeoenvironmental records other than ice cores into a precise climatic context. 


\section{Introduction}

\subsection{Linking of Greenland and Antarctic ice core records}

Synchronization of palaeo-environmental records in ice cores from Greenland and Antarctica has long been a topic of great interest. In Greenland, glacial climate is associated with a number of abrupt climate shifts, Dansgaard-Oeschger (DO) events (Dansgaard et al., 1993), whereas Antarctica experienced a number of more gradual climate variations, Antarctic Isotope Maxima (AIM) (EPICA community members, 2006). A precise linking of ice cores from the two hemispheres is essential to determine the exact sequence of events and to reveal the dynamics related to these climate changes. Furthermore, because many palaeo-environmental archives can be linked to polar ice cores (Blockley et al., 2012), a north-south synchronization of polar ice cores provides a way to place those archives into a global climatic context.

A number of different approaches have been taken to synchronize ice cores from the two hemispheres. Bender et al. (1994) used the global signal of oxygen isotopes of air trapped in the Greenland GISP2 and the Antarctic Vostok ice cores to link the two climatic records during the last glacial period. Blunier et al. (1998) and later Blunier and Brook (2001) applied the atmospheric methane concentration records extracted from the Greenland GISP2 and GRIP cores and the Antarctic Vostok and Byrd cores to construct a relative bipolar ice core chronology for the last $90 \mathrm{ka}$. Methane records were also applied to link the Greenland NGRIP (North Greenland Ice Core Project members, 2004) and the Antarctic EDML (EPICA community members, 2006) ice cores for the last $50 \mathrm{ka}$ and to show that indeed all Greenland DO events have Antarctic AIM counterparts. More recently, Capron et al. (2010b) applied both methane concentration and oxygen isotopes of air to link NGRIP and EDML for the time period 80-123 ka BP. Because air bubbles are incorporated in ice cores at the depth where firn is compacted to ice, the age of the ice and the age of the gas record in an ice core are offset by the so-called "delta age" (Schwander et al., 1993; Buizert et al., 2012). This age offset depends primarily on accumulation, firn thickness, temperature, and possibly the impurity content of the ice (Goujon et al., 2003; Hörhold et al., 2012). Therefore, uncertainties of the order of 100-1000 yr remain in synchronizing ice core climatic signals using gas-based matching (Blunier et al., 2007).

A different approach of inter-hemispheric ice core linking was taken by Raisbeck et al. (2007), who applied the global signal of cosmogenic ${ }^{10} \mathrm{Be}$ in ice cores to match the Greenland GRIP and the Antarctic EDC ice cores at the Laschamp geomagnetic excursion that occurred about $41 \mathrm{ka}$ ago. The

${ }^{10} \mathrm{Be}$ approach does not involve a delta age as it directly links horizons in the ice phase of the cores in question. At the Laschamp excursion, which is characterized by a characteristic double spike in ${ }^{10} \mathrm{Be}$ records, the Greenland and
Antarctic ice cores could be linked with decadal precision. The Laschamp excursion also provides a constraint for the delta age estimation (Loulergue et al., 2007).

Both gas and ${ }^{10} \mathrm{Be}$ linking was applied to tie the Antarctic EDML (Ruth et al., 2007) and EDC (Parrenin et al., 2007) ice cores to the Greenland NGRIP ice core, whereby the unified Greenland Ice Core Chronology 2005 (GICC05) (Rasmussen et al., 2006; Andersen et al., 2006) could be transferred to Antarctica back to $41 \mathrm{kaBP}$. This approach was refined and extended by Lemieux-Dudon et al. (2010), who applied an inverse model to combine the ice core time scales for NGRIP, EDC, EDML, and Vostok and the stratigraphic constraints among those cores to obtain a unified and consistent set of age scales for both ice and gas records. Recently, this approach has been further extended for construction of the Antarctic Ice Core Chronology 2012 (AICC2012) (Bazin et al., 2012; Veres et al., 2012).

The linking of Greenland and Antarctic ice cores paved the way for the bipolar seesaw hypothesis, which suggests a mechanism to link the millennium scale climate variability of the last glacial period between the hemispheres (Broecker, 1998; Stocker and Johnsen, 2003). The bipolar seesaw hypothesis suggests that the Greenland DO events and the Antarctic AIM events are linked through the Atlantic Meridional Overturning Circulation (AMOC) implying that a warming in Greenland causes a cooling in Antarctica and vice versa. Blunier et al. (1998) and consecutive publications show that the picture is more complex: a rapid warming in Greenland ends a slow warming in Antarctica, which conceptually can be explained by adding a heat buffer in the Southern Ocean (Stocker and Johnsen, 2003). The EDML ice core is thought to have a strong expression of the bipolar seesaw due to its location in the Atlantic sector of Antarctica. Within the last $50 \mathrm{ka}$ the Greenland-Antarctic ice core linking is well established, and the bipolar seesaw hypothesis appears to be confirmed by the relative timing of climate events (EPICA community members, 2006; Lemieux-Dudon et al., 2010; Stenni et al., 2010; Pedro et al., 2011). Beyond this time window, the relative timing of $\mathrm{N}-\mathrm{S}$ records is somewhat uncertain, but the bipolar seesaw hypothesis appears to be active throughout the last glacial period (Blunier and Brook, 2001; Jouzel et al., 2007). During the earliest part of the last glacial the bipolar seesaw may have had somewhat different characteristics (Capron et al., 2010a), but in this period the ice core chronologies are still being adjusted (Vallelonga et al., 2012).

Recently, the Greenland NGRIP and Antarctic EDML ice cores have been linked over the last $17 \mathrm{ka}$ through layer counting and matching of bipolar volcanic markers identified in both ice cores (Vinther et al., 2012); the two ice cores were dated independently by annual layer counting, NGRIP using the existing GICC05 chronology (Vinther et al., 2006; Rasmussen et al., 2006) and EDML by application of a multiparameter high-resolution continuous flow analysis (CFA) dataset. The ice cores were then synchronized using major 
volcanic events that are unambiguously identified in both cores and thereby allowing for a highly precise transfer of the Greenland GICC05 timescale to EDML ice core (Vinther et al., 2012).

\subsection{The Toba eruption occurring around $74 \mathrm{ka} \mathrm{BP}$}

The Toba caldera is located close to the equator in northern Sumatra, Indonesia. Over the last 1.3 million years, the volcano has had several very large eruptions of which the most recent that occurred some $74 \mathrm{ka}$ ago is considered one of the largest volcanic eruptions of the Quaternary (Chesner, 2012). Tephra from this eruption, known as Younger Toba Tuff (YTT), is spread over a vast geographical region in south-eastern Asia on both sides of the equator and has been identified at many locations in the surrounding oceans and continents (e.g. Williams, 2012). The YTT geochemistry is well characterized (Westaway et al., 2011), and age estimates of the YTT are provided in several studies by application of various techniques (e.g. Chesner et al., 1991). Most recently, well-characterized Toba tephra sampled in Malaysia has been precisely dated by Ar-Ar to $73.88 \pm 0.32 \mathrm{ka} \mathrm{BP}(1-$ sigma) by Storey et al. (2012), and material from both Sumatra and sites in India were dated by Ar-Ar to $75.0 \pm 0.9 \mathrm{ka}$ (1-sigma) by Mark et al. (2013).

So far, tephra originating from Toba has not been identified in Greenland (Abbott et al., 2012) or in Antarctic ice cores. Already in 1996, however, Zielinski et al. (1996) suggested that the Toba eruption could be associated with a major sulphuric spike identified in the Greenland GISP2 ice core at the transition from Greenland Interstadial 20 (GI-20) to Greenland Stadial 20 (GS-20) occurring close to the Marine Isotope Stage 4/5 (MIS 4/5) boundary. A few years later, Toba tephra was identified in marine sediment cores from the Arabian Sea, which show a glacial climate variability comparable to that of the Greenland ice cores (Schulz et al., 1998). The position of the tephra in those and several other marine records seems to confirm the timing of the Toba eruption at the GI-20 to GS-20 transition (Schulz et al., 2002; Kudrass et al., 2001; Huang et al., 2001).

Being a much larger eruption than any historical eruption and probably being among the largest volcanic eruptions of the Quaternary, the environmental and climatic effects of the $74 \mathrm{ka}$ BP Toba eruption are topics of great interest and debate. The suggested climatic impact of the Toba eruption ranges from very little impact (Haslam and Petraglia, 2010; Oppenheimer, 2002; Chesner and Luhr, 2010) to severe impact of "volcanic winter and accelerated glaciation" (Rampino and Self, 1992). The effect of the eruption on regional vegetation, humans, and mammals is discussed in a number of papers (e.g. Petraglia et al., 2007; Louys, 2012) and the topic is still controversial (Williams, 2012). For archaeology the Toba eruption is of particular interest because it may have occurred close to the time when Homo sapiens migrated out of Africa and into Eurasia (Rasmussen et al.,
2011) and it is speculated that the eruption may have caused a "human population bottleneck" (Ambrose, 1998). Beyond the climate impacts of the Toba eruption, the event provides an important, distinct and widespread time marker beyond the ${ }^{14} \mathrm{C}$ dating range (e.g. Lane et al., 2011).

\subsection{Outline of the present study}

Inter-hemispheric volcanic linking of ice cores is quite different from volcanic ice core synchronization within Greenland or within Antarctica. In Greenland the volcanic record is dominated by Northern Hemisphere eruptions and major eruptions are generally present in all deep ice cores despite a large spatial variability of volcanic deposition on the ice sheet (Clausen et al., 1997; Robock, 2000). Greenland ice cores have been synchronized in the last glacial period at annual-to-decadal precision by major volcanic reference horizons (Rasmussen et al., 2008). Due to its large geographical extent, the spatial variability of volcanic deposition is even more pronounced in Antarctica, but ice cores can still be linked accurately by volcanic tie points (Severi et al., 2007; Parrenin et al., 2012). For globally dispersed volcanic events, the magnitude of Greenland and Antarctic acidic signatures will generally not be comparable as they depend strongly on several factors, such as latitude of the eruption, atmospheric circulation, and the amount of sulphur injected into the stratosphere (Zielinski, 2000; Gao et al., 2008). Therefore, it is not straightforward to establish a Greenland-Antarctic volcanic ice core synchronization from acidity spikes alone and, in general, additional evidence is needed in order to establish a bipolar volcanic link (Bay et al., 2006).

In this study we take a similar approach to that applied for the last $17 \mathrm{ka}$ by Vinther et al. (2012) of matching Greenland and Antarctic ice cores by annual layer counting and linking of bipolar volcanic reference horizons. The independent dating of Greenland and Antarctic ice cores by annual layer counting permits matching of sequences of globally dispersed volcanic markers. To demonstrate the feasibility of this technique in the last glacial period, we first establish a volcanic link of the Greenland NGRIP and Antarctic EDML ice cores at the Laschamp geomagnetic excursion (41 ka BP), where the $\mathrm{N}-\mathrm{S}$ linking is already well constrained. In this period we apply the existing layer-counted GICC05 chronology for NGRIP and count annual layers in EDML, using a highresolution impurity dataset. We then extend this approach to a $2000 \mathrm{yr}$ period at around $74 \mathrm{ka} \mathrm{BP}$ where prominent acidity spikes that are most likely related to the Toba eruption can be identified in both NGRIP and EDML. Annual layer counting is performed independently in NGRIP and EDML, and based on the relative chronologies an inter-hemispheric match is obtained by identifying a sequence of volcanic markers that are recognized in both cores. Based on published and new tie points we then expand the $\mathrm{N}-\mathrm{S}$ Toba link to other major Greenland and Antarctic ice cores. 


\section{Datasets and methods}

For annual layer counting in NGRIP, we apply the highresolution CFA impurity dataset (Bigler, 2004) that provides continuous records of among others sulphate, sodium, calcium, electrolytic conductivity of melt water ("conductivity"), and the amount of insoluble dust particles ("dust") (Ruth et al., 2003) together with the visual stratigraphy (VS) greyscale profile (Svensson et al., 2005). Those records were previously applied to construct the glacial part of the GICC05 time scale (Rasmussen et al., 2006; Svensson et al., 2008). For the EDML layer counting we apply a CFA high-resolution dataset that provides continuous records of sodium, ammonium, calcium, dust, and conductivity (Kaufmann et al., 2010) as well as the VS greyscale profile (Faria et al., 2010). This CFA dataset was applied to establish the layer-counted EDML time scale for the last $17 \mathrm{ka}$ (Vinther et al., 2012). All of the records are available in $1 \mathrm{~mm}$ depth resolution, but due to varying degrees of profile smoothing in the firn and ice and during ice core analysis, the minimum resolvable features differ from record to record. The CFA records can typically resolve annual layers down to a few $\mathrm{cm}$ thickness, whereas the VS greyscale profiles can easily resolve annual layers of $1 \mathrm{~cm}$ thickness.

To identify volcanic markers in NGRIP, we apply the CFA sulphate and conductivity records, the electrical conductivity measurement (ECM) (Dahl-Jensen et al., 2002), and the dielectric profile (DEP) (Wilhelms et al., 1998). NGRIP ECM and DEP do not usually resolve annual layers in the glacial period, but they are good indicators of volcanic events, in particular during interstadials. For EDML volcanic markers were identified in the CFA conductivity, in DEP and ECM, and in sulphate, all of which are robust indicators of volcanic events that have previously been applied to match Antarctic ice core records (Udisti et al., 2004; Parrenin et al., 2012; Severi et al., 2007).

\section{Bipolar synchronization at the Laschamp geomagnetic excursion}

At the Laschamp geomagnetic excursion that occurred close to $41 \mathrm{ka}$ BP (Singer et al., 2009), a bipolar synchronization is already established based on two ${ }^{10} \mathrm{Be}$ spikes identified in both Greenland and Antarctic ice cores (Raisbeck et al., 2007; Yiou et al., 1997). The two ${ }^{10} \mathrm{Be}$ peaks essentially bracket the Greenland GI-10 event that is associated with the Antarctic AIM-9 and -10 events. In NGRIP the youngest of the ${ }^{10} \mathrm{Be}$ peaks occurs very close to the onset of GS-10 and the oldest peak is located towards the end of GS-11. In NGRIP the two peaks are separated by some $17.5 \mathrm{~m}$, corresponding to an interval of about $850 \mathrm{yr}$ duration. The precision of the ${ }^{10} \mathrm{Be}$ NGRIP-EDML synchronization is decadal to centennial (Raisbeck et al., 2007; Loulergue et al., 2007).
The Laschamp section of the NGRIP ice core has been dated by annual layer counting for the GICC05 chronology which we adapt here (Andersen et al., 2006). We date the Laschamp section of the EDML ice core by layer counting in the CFA and VS datasets following the same principles as applied for NGRIP. We identify "certain" and "uncertain" annual layers that are counted as $1.0 \pm 0.0$ and $0.5 \pm 0.5 \mathrm{yr}$, respectively. The accumulated uncertainty of the uncertain annual layers provides the maximum counting error estimate of the dating following the approach outlined in Andersen et al. (2006). The EDML mean annual layer thickness for the Laschamp section of around two $\mathrm{cm}$ is well resolved in the VS record, fairly well resolved in dust, calcium, and ammonium, but only partially resolved in conductivity (Fig. 1). The resulting relative time scale is presented in Table 1.

Figure 2 shows the ${ }^{10} \mathrm{Be}$ matched section of the two ice cores around the Laschamp event with indication of the two

${ }^{10}$ Be peaks. In NGRIP the impurity load is strongly climate dependent (as determined by $\delta^{18} \mathrm{O}$ ) with generally higher impurity loading during the cold phases/stadials as the wellknown Greenland pattern (Mayewski et al., 1997; Fischer et al., 2007b). During interstadials volcanic spikes are usually quite distinct and easy to identify, whereas in the coldest periods the volcanic spikes are often difficult to separate from the generally higher and noisier background level (Fig. 2). We note that because prominent sulphate peaks normally dominate the conductivity of the ice, the sulphate and the conductivity records are both robust indicators of major volcanic events.

Between the two Laschamp ${ }^{10} \mathrm{Be}$ peaks, the NGRIP records show evidence of 3-5 larger and several smaller volcanic events, whereas EDML has expression of 3-4 significant volcanic markers and some smaller events. Based on the ${ }^{10} \mathrm{Be}$ matching and on the annual layer counting of the two ice core sections, we suggest that three of those events (referred to as L1-L3) are bipolar and can be applied to synchronize the ice cores (Fig. 2 and Table 1). Because we have no tephra evidence, there is no way to prove that the suggested match points are truly global markers, and potentially one or more of them are regional events that are just lining up by coincidence. Considering, however, the few volcanic events over the $850 \mathrm{yr}$ period of interest and the tight correspondence in the relative timing of events, a coincidental overlap of all of the events appears unlikely. The larger discrepancy in number of years between match points ${ }^{10} \mathrm{Be}$ 1 and L1 between the two cores can be readily attributed to the $30-50 \mathrm{yr}$ uncertainty of the north-south ${ }^{10} \mathrm{Be}$ linking (Raisbeck et al., 2007).

\section{Bipolar volcanic linking at the $74 \mathrm{ka}$ BP Toba eruption}

Because no Toba tephra has been identified in polar ice cores, we do not have any proven knowledge of the location of the 


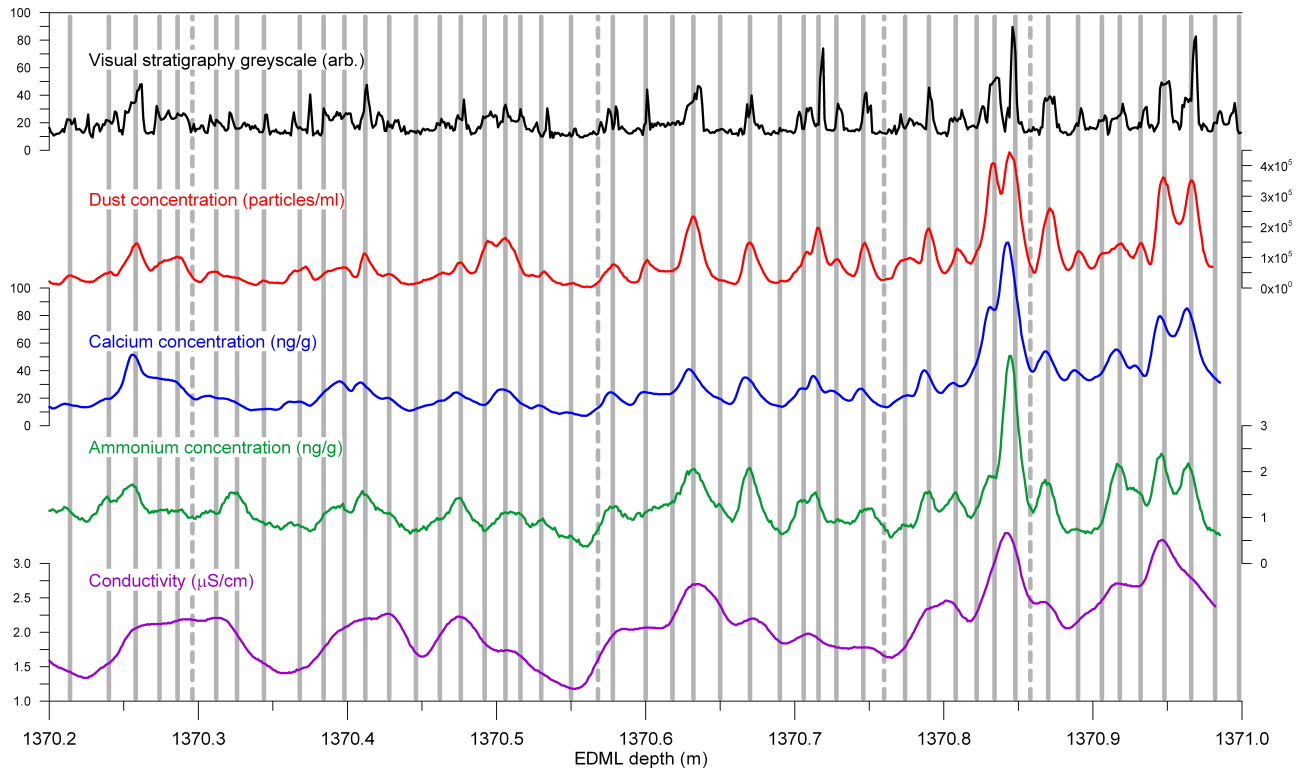

Fig. 1. Example of layer counting in the EDML ice core at the Laschamp event. Annual layers are indicated by grey vertical bars. Solid and dashed vertical bars indicate "certain" and "uncertain" layers, respectively.

Table 1. Depth, and absolute and relative age of Laschamp and Toba match points in the NGRIP and EDML ice cores based on the GICC05modelext time scale (Wolff et al., 2010) and on layer counting (this work). "b2k" refers to "before year 2000 AD".

\begin{tabular}{|c|c|c|c|c|c|c|}
\hline \multirow[b]{2}{*}{ Match point } & \multicolumn{2}{|c|}{ Ice core depth $(\mathrm{m})$} & \multicolumn{2}{|c|}{ GICC05modelext age (yr b2k) } & \multicolumn{2}{|c|}{ Layer counting (yr) } \\
\hline & NGRIP & EDML & Absolute & Relative & NGRIP & EDML \\
\hline \multicolumn{7}{|c|}{ Laschamp event interval } \\
\hline $10 \mathrm{Be}-1$ & 2110.10 & 1368.40 & 40823 & 0 & $0 \pm 0$ & $0 \pm 0$ \\
\hline L1 & 2111.58 & 1369.54 & 40912 & 89 & $89 \pm 3$ & $68 \pm 4$ \\
\hline L2 & 2115.41 & 1372.73 & 41109 & 285 & $285 \pm 8$ & $262 \pm 13$ \\
\hline L3 & 2118.62 & 1375.15 & 41249 & 425 & $425 \pm 11$ & $404 \pm 24$ \\
\hline $10 \mathrm{Be}-2$ & 2127.50 & 1383.30 & 41690 & 867 & $867 \pm 36$ & $854 \pm 54$ \\
\hline \multicolumn{7}{|c|}{ Toba event interval } \\
\hline $\mathrm{T} 1$ & 2547.22 & 1866.62 & 74057 & 0 & $0 \pm 0$ & $0 \pm 0$ \\
\hline $\mathrm{T} 2$ & 2547.97 & 1867.56 & 74156 & 99 & $87 \pm 6$ & $84 \pm 7$ \\
\hline $\mathrm{T} 3$ & 2550.06 & 1869.51 & 74358 & 301 & $276 \pm 18$ & $264 \pm 21$ \\
\hline $\mathrm{T} 4$ & 2551.45 & 1870.93 & 74484 & 427 & $395 \pm 24$ & $388 \pm 27$ \\
\hline T5 & 2558.43 & 1877.57 & 75039 & 982 & $947 \pm 53$ & $953 \pm 66$ \\
\hline T6 & 2558.76 & 1877.85 & 75064 & 1007 & $972 \pm 56$ & $978 \pm 68$ \\
\hline $\mathrm{T} 7$ & 2564.35 & 1882.96 & 75479 & 1422 & $1386 \pm 80$ & $1384 \pm 93$ \\
\hline $\mathrm{T} 8$ & 2564.70 & 1883.31 & 75505 & 1448 & $1413 \pm 82$ & $1411 \pm 93$ \\
\hline T9 & 2572.61 & 1890.58 & 76037 & 1980 & $1951 \pm 114$ & $1959 \pm 128$ \\
\hline
\end{tabular}

Toba volcanic signature neither in Greenland nor in Antarctic ice cores. The approach taken here to establish the bipolar Toba link takes two steps: first, we provide an estimate for the position of the Toba eruption in the NGRIP and EDML ice cores based on recent independent dating of the event and on the bipolar seesaw hypothesis. Second, we perform layer counting in a 2000-yr-long section of the two cores around the proposed Toba location and show that a bipolar volcanic synchronization can be established. Having done this, we still have not proven to have identified Toba in the ice cores, but we have increased the likelihood substantially and we have provided a bipolar volcanic link for the time interval, where we know from other geological evidence that the Toba eruption must have occurred.

Zielinski et al. (1996) were the first to suggest the position of the Toba volcanic marker in Greenland at the GI-20 to GS-20 transition, and further evidence for this location was provided by the finding of the Toba tephra in the Arabian 


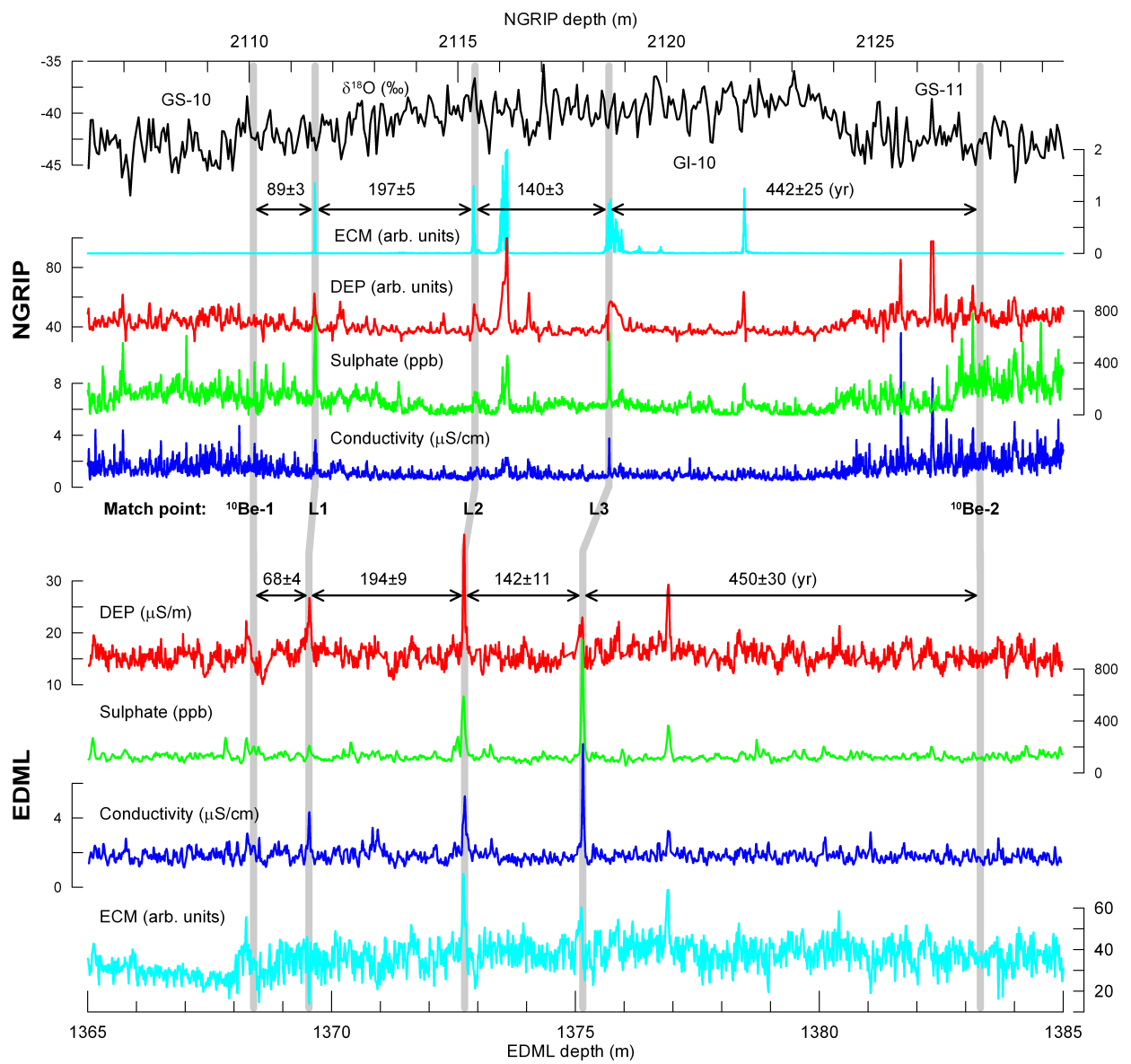

Fig. 2. Matching of NGRIP and EDML ice cores around the two ${ }^{10} \mathrm{Be}$ peaks associated with the Laschamp geomagnetic excursion (41.25 ka $\mathrm{b} 2 \mathrm{k})$. Grey vertical bars indicate NGRIP-EDML match points. The outermost match points $\left({ }^{10} \mathrm{Be}-1\right.$ and $\left.{ }^{10} \mathrm{Be}-2\right)$ indicate the ${ }^{10} \mathrm{Be}$ synchronization provided by Raisbeck et al. (2007) and Loulergue et al. (2007). The three match points (L1-L3) indicate the proposed volcanic matching. The number of years counted between match points is indicated.

Sea (Schulz et al., 1998). New well-constrained Ar-Ar ages for the Toba YTT eruption of $73.88 \pm 0.32 \mathrm{kaBP}$ (Storey et al., 2012) and of $75.0 \pm 0.9 \mathrm{ka} \mathrm{BP}$ (Mark et al., 2013) have become available. Recently, a record of several stalagmites from caves in the Alps (NALPS), showing a climatic pattern very similar to that of the Greenland ice cores, has been precisely dated by U-Th (Boch et al., 2011). Although the NALPS stalagmite record does not contain the onset of GS20, it unambiguously brackets the Toba YTT ages between the onsets of GI-19 and GI-20. The new tephra ages and the stalagmites thus provide additional and independent evidence for the location of the Toba event close to the onset of GS-20 in Greenland. The new YTT ages also agree within uncertainties to the Greenland GICC05modelext ice core time scale age of $74.1 \mathrm{kab} 2 \mathrm{k}$ (before year $2000 \mathrm{AD}$ ) for the onset of GS-20 (Wolff et al., 2010), but the absolute ice core age is much less well constrained than that of the NALPS record due to the cumulative error of ice core annual layer counting.

According to the linking of Greenland and Antarctic ice cores (Blunier and Brook, 2001; Jouzel et al., 2007; Capron et al., 2010b), and consistent with the bipolar seesaw hypothesis (Stocker and Johnsen, 2003), the onset of Greenland GS-20 is associated with the isotopic minimum between Antarctic AIM-19 and AIM-20 (Parrenin et al., 2012). We therefore examine this region of the NGRIP and EDML ice cores for significant volcanic markers (Fig. 3). In NGRIP the well-known pattern of elevated impurity content in the stadial periods is apparent. The major acidity spikes in the GI20 and GS-20 intervals appear, however, within GI-20 close to the isotopic transition into GS-20 and the most significant spike in sulphate and conductivity appears at the depth of $2548.01 \mathrm{~m}$ right on the transition. In the interstadial, acidity spikes are also visible in ECM and DEP, whereas those records vanish in stadials where the ice is slightly alkaline (Wolff et al., 1997). In EDML the most prominent conductivity, DEP, and ECM spikes in the AIM-19 and AIM-20 intervals appear around the isotopic minimum between the two and the most significant spike occurs at a depth of $1867.56 \mathrm{~m}$ (Fig. 3).

For layer counting in the potential Toba region we apply the same counting technique and the same NGRIP and 
Table 2. Depths of Laschamp and Toba match points in Greenland (NGRIP, GISP2, and GRIP) and Antarctic (EDML, EDC, DF-1, DF-2, Vostok) ice cores. The EDML-EDC matching is from Severi et al. (2007) and Ruth et al. (2007), the EDC-Vostok matching is from Parrenin et al. (2012), and the Laschamp ${ }^{10} \mathrm{Be}$ match is from Raisbeck et al. (2007) and Loulergue et al. (2007).

\begin{tabular}{|c|c|c|c|c|c|c|c|c|}
\hline & $\begin{array}{l}\text { NGRIP } \\
\text { Units are }\end{array}$ & $\begin{array}{r}\text { GRIP } \\
\text { in metres }\end{array}$ & GISP2 & EDML & EDC & DF-1 & DF-2 & Vostok 5G \\
\hline \multicolumn{9}{|c|}{ Laschamp event interval } \\
\hline $10 \mathrm{Be}-1$ & 2110.10 & 2231.90 & & 1368.40 & & & & \\
\hline L1 & 2111.58 & 2233.02 & 2265.61 & 1369.54 & & & & \\
\hline L2 & 2115.41 & 2236.21 & 2268.96 & 1372.73 & 738.19 & & & \\
\hline L3 & 2118.62 & 2238.90 & 2271.77 & 1375.15 & 739.80 & & & \\
\hline $10 \mathrm{Be}-2$ & 2127.50 & 2246.20 & & 1383.30 & & & & \\
\hline \multicolumn{9}{|c|}{ Toba event interval } \\
\hline $\mathrm{T} 1$ & 2547.22 & 2564.68 & 2591.10 & 1866.62 & 1078.96 & & 1165.83 & 1035.00 \\
\hline $\mathrm{T} 2$ & 2547.97 & 2565.18 & 2591.64 & 1867.56 & 1079.72 & 1167.29 & 1166.59 & 1036.00 \\
\hline $\mathrm{T} 3$ & 2550.06 & 2566.58 & 2593.03 & 1869.51 & 1081.27 & & 1168.29 & 1038.45 \\
\hline $\mathrm{T} 4$ & 2551.44 & 2567.46 & 2593.87 & 1870.93 & 1082.29 & 1170.11 & 1169.42 & \\
\hline T5 & 2558.43 & 2572.20 & 2598.54 & 1877.57 & & & & \\
\hline T6 & 2558.76 & & & 1877.85 & 1087.94 & 1175.74 & 1175.04 & 1048.35 \\
\hline $\mathrm{T} 7$ & 2564.35 & & & 1882.96 & & & & \\
\hline $\mathrm{T} 8$ & 2564.70 & & & 1883.31 & & & & \\
\hline T9 & 2572.61 & 2581.30 & 2607.91 & 1890.58 & 1097.96 & 1185.55 & 1184.89 & 1063.00 \\
\hline
\end{tabular}

EDML datasets that were utilized for the Laschamp matching. Compared to Laschamp we are now some $500 \mathrm{~m}$ deeper in both cores, and annual layers are correspondingly thinner. At NGRIP, annual layers in GI-20 have a thickness of $1.0-1.5 \mathrm{~cm}$ that is well resolved in the VS record, but only marginally resolved in the CFA data (Fig. 4). The approximately 2-ka-long section in GI-20 is dated in a similar manner as it was done at shallower depths for sections of GICC05 (Svensson et al., 2008). In the subsequent stadial GS-20, however, annual layer thicknesses are below $1 \mathrm{~cm}$ and this period cannot be reliably dated using existing datasets. The obtained NGRIP layer thickness profile is in very good agreement with that of the modelled "ss09sea" time scale (not shown). In EDML, annual layers have comparable layer thicknesses of $1.0-1.5 \mathrm{~cm}$, which are again well resolved in VS and marginally resolved in CFA (Fig. 5). The EDML layer thickness profile obtained from layer counting is in very good agreement with the time scale of Lemieux-Dudon et al. (2010) and deviates somewhat from the EDML1 time scale of Ruth et al. (2007) (Fig. 6).

We now synchronize the two ice cores by identifying a sequential pattern of acidity tie points (Fig. 7 and Table 1). The proposed match has nine match points (referred to as T1-T9), of which the major NGRIP and EDML acidity spike (T2) is one. The matching is seen to be particularly well constrained in the younger part, where four strong unevenly distributed acidity spikes provide a unique sequence. Interestingly, most of the EDML acidity spikes in this period apparently have a counterpart in Greenland, suggesting that they all originate from low-latitude eruptions.

\section{Discussion}

\subsection{Are there several Toba YTT eruptions?}

In the ice core records investigated in the present study, there are four bipolar acidity spikes (T1-T4) occurring within centuries of the GS-20 onset that are all potential Toba eruption candidates (Fig. 7). Based on the ice core data alone, we have no means of determining how many of those events may be related to Toba. In the study of Storey et al. (2012), the precise Toba dating of several samples cluster around the age of $73.88 \pm 0.32 \mathrm{ka} \mathrm{BP}$, and in the study of Mark et al. (2013) ages fall in the range of $75.0 \pm 0.9 \mathrm{ka} \mathrm{BP}$, but the temporal resolution of the Ar-Ar technique does not exclude the existence of several Toba eruptions separated by centuries.

In the bipolar match presented here, the T2 match point corresponds to the major acidity spikes in both the NGRIP and EDML ice cores (Fig. 7), but, interestingly, this is generally not the case for other ice cores (Fig. 8). In the GISP2 core, the major sulphate spike identified by Zielinski et al. (1996) at $2591.1 \mathrm{~m}$ depth thus corresponds to the match point T1 of the present study (Table 2). Smaller spikes are also present in this depth interval of the GISP2 sulphate record, but the peak corresponding to $\mathrm{T} 1$ is definitely dominating. In high depth resolution the GISP2 sulphate concentrations at T1 are reaching almost 2000 ppb (Yang et al., 1996) in comparison to $1200 \mathrm{ppb}$ for NGRIP at T2. In the nearby GRIP ice core, the overall behaviour of the ECM record is very similar to that of the GISP2 ECM record, but the $\mathrm{T} 1$ peak is strongly attenuated in GRIP as compared to GISP2. In the Antarctic EDC ice core the major acidity spike in the Toba interval is associated with match point $\mathrm{T} 3$ of the 


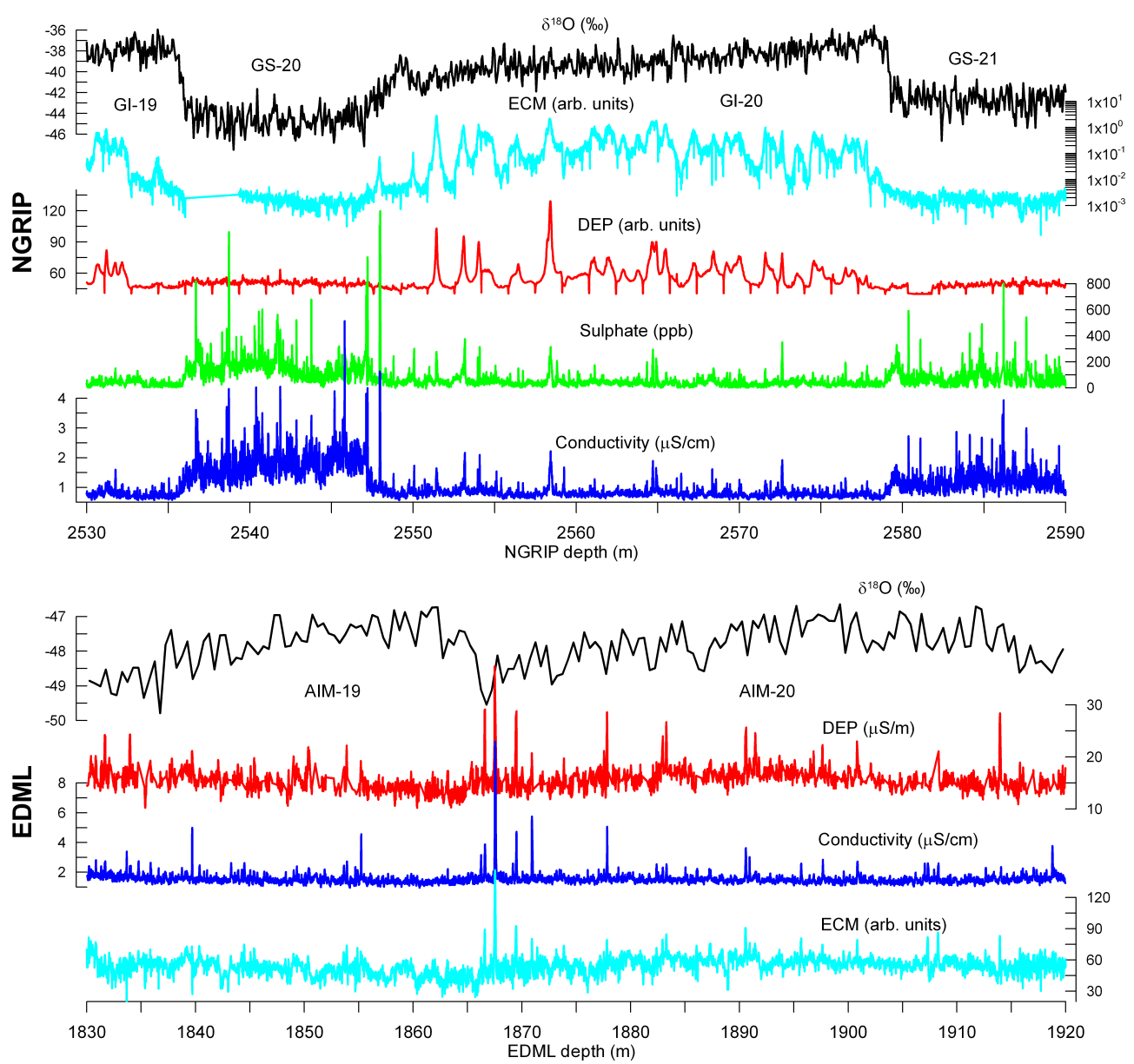

Fig. 3. Overview of NGRIP records around GS-20/GI-20 and of EDML records around AIM-19/20.

present study, although the acidity spikes corresponding to $\mathrm{T} 1$ and $\mathrm{T} 2$ are also prominent. In the Dome Fuji (DF) ECM records, the spike associated with $\mathrm{T} 4$ is the strongest, $\mathrm{T} 2$ is significant, and T3 is very weak. In the Vostok ice core ECM profile the T1 peak is the strongest followed by slightly weaker T2 and T3 peaks (Parrenin et al., 2012). Based on ice core data there are thus several possible candidates for Toba eruption(s), and it cannot be excluded that several of them are related to Toba.

Recently, Sigl et al. (2012) identified some 50 bipolar volcanoes over the last two millennia. It is, therefore, not a surprise to find several bipolar events in a similar time span at around $74 \mathrm{ka} \mathrm{BP}$. The surprising thing is that none of the events stand out as an exceptional event, considering the magnitude of the Toba eruption. In the literature the $74 \mathrm{ka}$ BP Toba eruption is generally regarded as a single event (Westgate et al., 1998; Zielinski, 2000; Chesner, 2012). If there is just one Toba eruption, however, then the ice core records suggest the existence of several other large, unknown, lowlatitude eruptions occurring in the same time window.

Another well-known mega-eruption, the Huckleberry Ridge Tuff (HRF) "Yellowstone" eruption occurring some
2.1 million years ago was recently determined to consist of three distinct eruptions separated by some thousands of years (Ellis et al., 2012). In this case, however, the individual eruption events could also be distinguished by other means, such as isotopic fingerprinting of the lava flows. In the case of Toba, the YTT composition is much more homogeneous, and the potential temporal separation of individual events is hundreds rather than thousands of years. In contrast to the Yellowstone case, it is therefore not possible to decompose several potential Toba eruptions based on precise dating alone. Several closely spaced large Toba eruptions could, however, help to explain why none of the identified ice core events are as strong as would be expected from current geological evidence.

\subsection{Age and timing of the Toba event(s)}

Assuming that the major Toba eruption can be associated with one or several of the T1-T4 acidity spikes, the best Greenland ice core age estimates of the events are those of the GICC05modelext time scale (Wolff et al., 2010). Those ages fall in the interval of 74.1-74.5 kab2k (Table 1). Based 


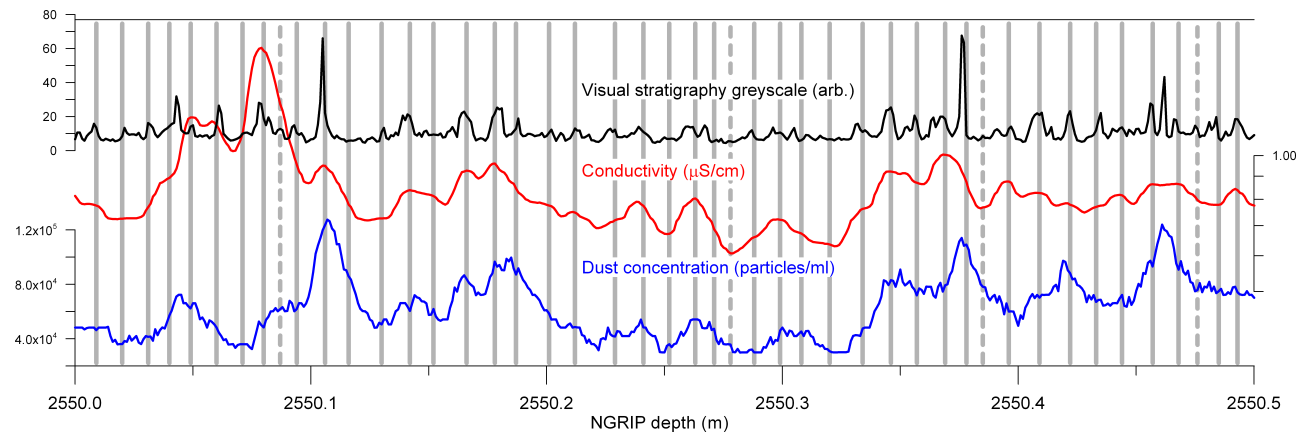

Fig. 4. Example of layer counting in the NGRIP ice core in GI-20. Notation as in Fig. 1.

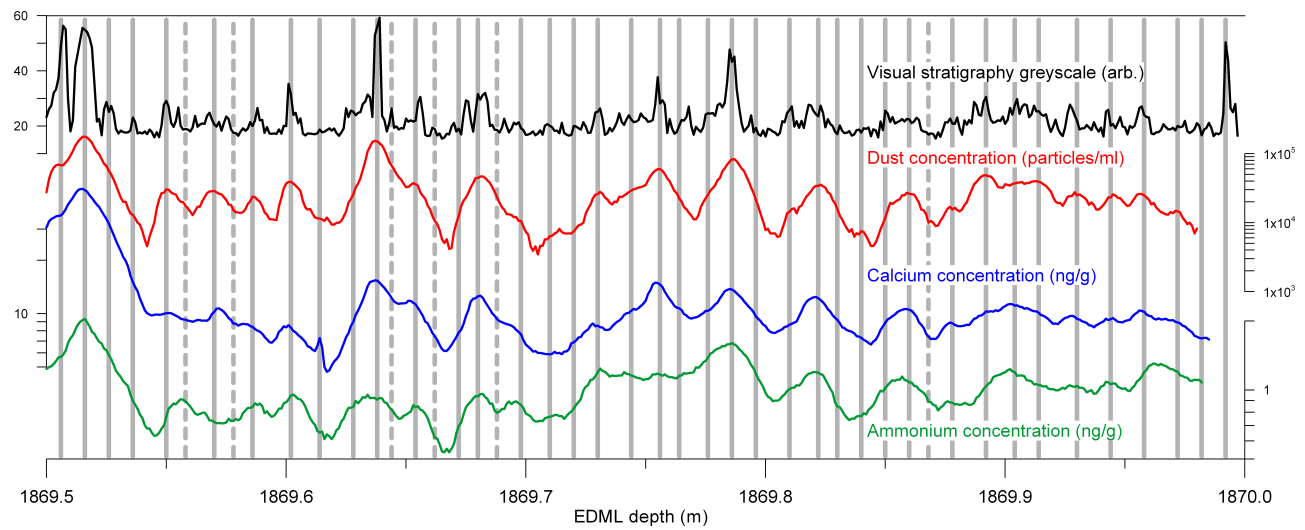

Fig. 5. Example of layer counting in the EDML ice core between AIM-19 and AIM-20. Notation as in Fig. 1.

on a $2.5 \%$ extrapolation of the GICC05 counting error up to $60 \mathrm{ka}$ (Svensson et al., 2008), the absolute uncertainty associated with the T1-T4 ice core ages is $1.7 \mathrm{ka}$. Within error estimates the ice core ages are fully in agreement with both the precise Ar-Ar dating of Storey et al. (2012) and that of Mark et al. (2013), as well as with the bracketing of the Toba event(s) by the European NALPS stalagmites (Boch et al., 2011). Concerning Antarctic ice core time scales, the EDML1/EDC3 time scale age for the Toba events T1-T4 is about 72.6 kab2k (Ruth et al., 2007; Parrenin et al., 2007), whereas the more recent Lemieux-Dudon et al. (2010) time scale give ages of 73.4-73.8 ka b2k with an absolute uncertainty of $2.3 \mathrm{ka}$. In East Antarctica, the acidity spikes associated with the Toba event(s) are likely to be the origin of a very strong radar sounding isochrone (Fujita et al., 2012; Cavitte et al., 2013).

As for the exact timing of the Toba candidates with respect to the GI-20 to GS-20 transition, we compare the position of the T1-T4 spikes to the NGRIP $\delta^{18} \mathrm{O}$ and deuterium excess (d-excess) profiles (Fig. 8). From a $\delta^{18} \mathrm{O}$ perspective T3 and T4 both occur within GI-20, whereas T1 and T2 both lie on the transition itself. Following the approach of Steffensen et al. (2008), we can identify an abrupt shift in the d-excess close to the $\mathrm{T} 2$ event that we associate with a rapid warming of the precipitation source area for NGRIP.
Within GI-20, d-excess is in "cold source area" mode. Close to $74200 \mathrm{yrb} 2 \mathrm{k}$ the d-excess makes a first jump to higher values and it is "flickering" until the occurrence of T2. From around $74100 \mathrm{yr}$ b2k onwards the d-excess remains in "warm source area" mode. As the d-excess mode jump is asynchronous with the Toba candidates we consider the timing of the NGRIP source area temperature change and the Toba events to be unrelated.

\subsection{Implication for the bipolar seesaw hypothesis}

The present study provides the oldest bipolar ice core synchronization at decadal precision. Because the Toba events are located right at a major climatic transition in Greenland, the synchronization allows for a very precise comparison of inter-hemispheric climate coupling. A detailed comparison of the oxygen isotope curves demonstrates an extremely close coupling between Greenland (NGRIP) and Antarctic (DF and EDC) climates (Fig. 9). At the GS-20 onset, Antarctic warming starts within a century of Greenland reaching the cold stadial and, likewise, at the onset of GI-19 and GI$20 \mathrm{DF}$ and EDC cooling starts immediately after Greenland has reached its isotopic maximum. Our results thus provide very strong support for an active bipolar seesaw close to the MIS4/5 boundary similar to what is observed in other parts of 


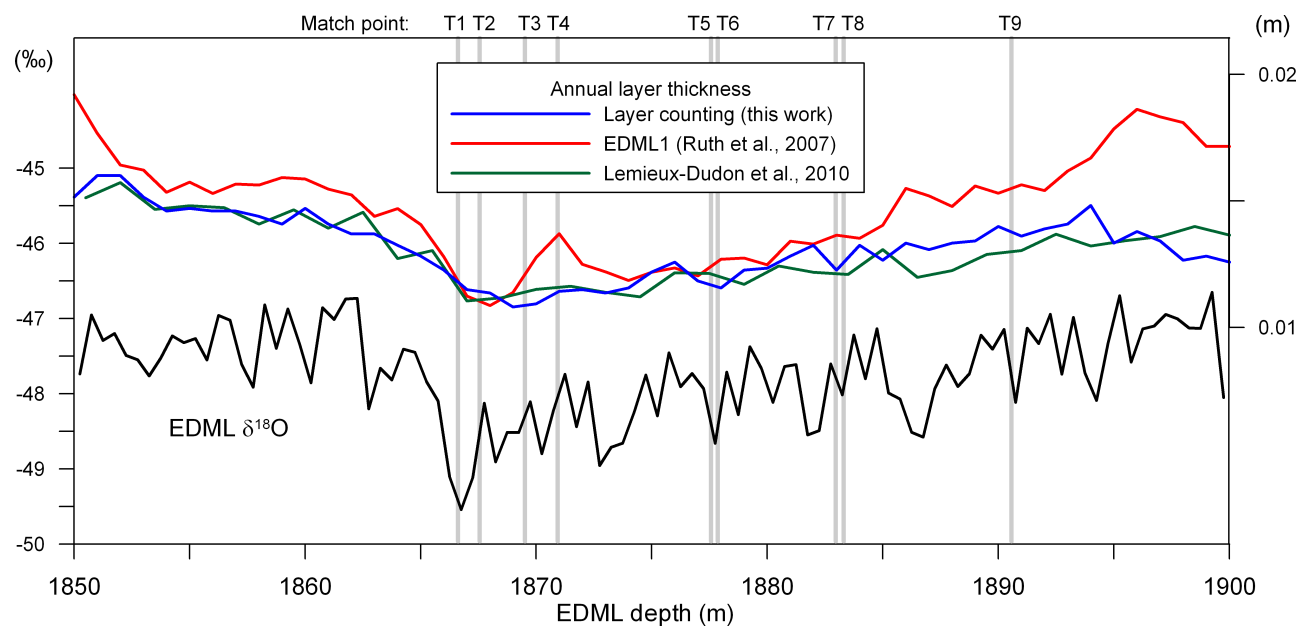

Fig. 6. Annual layer thicknesses around the Toba candidates according to layer counting (this work), the EDML1 time scale of Ruth et al. (2007), and the time scale by Lemieux-Dudon et al. (2010).

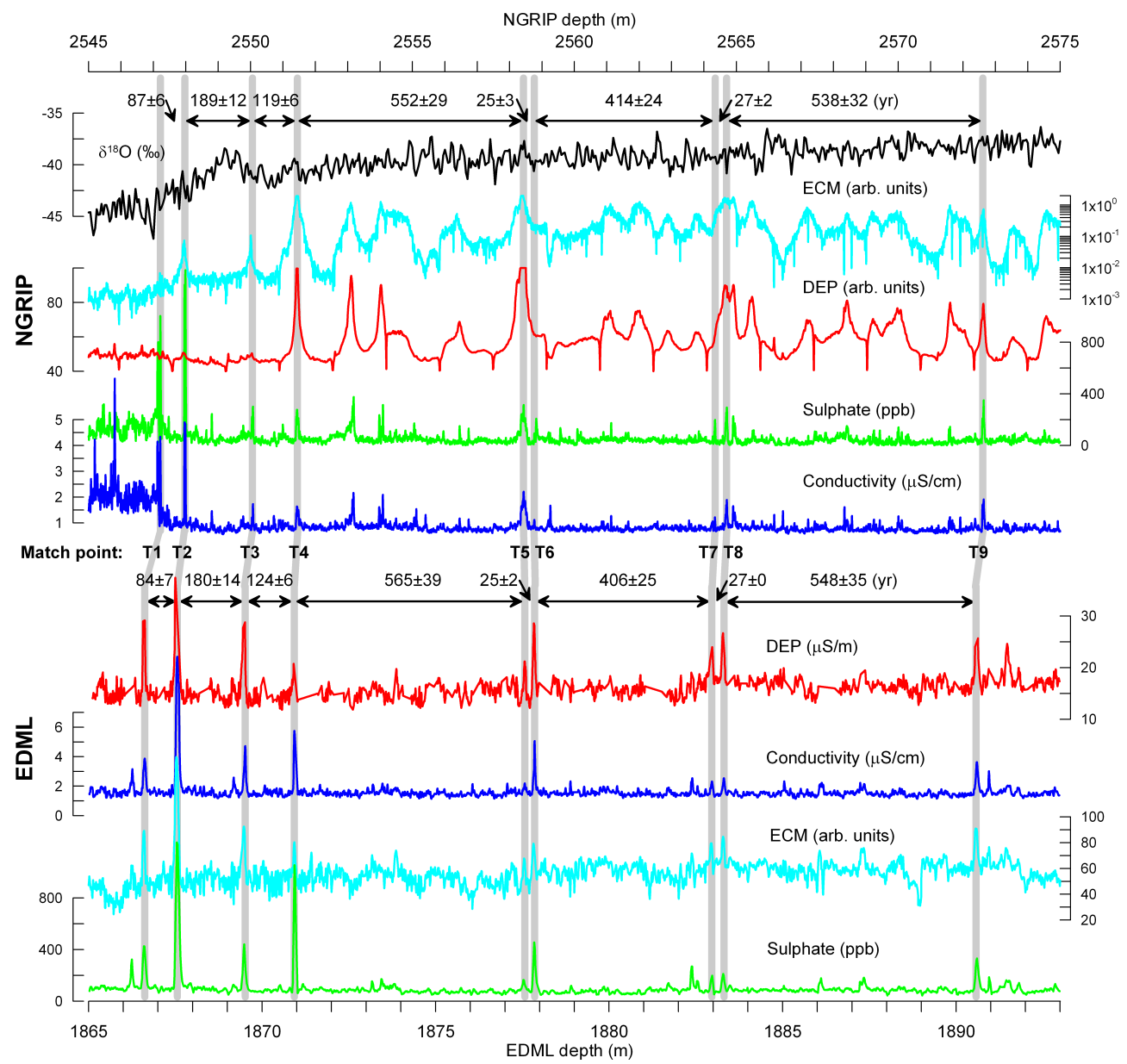

Fig. 7. Matching of NGRIP and EDML ice cores at around GI-20 showing the suggested $74 \mathrm{ka}$ BP Toba synchronization. The grey vertical bars indicate NGRIP - EDML volcanic match points (T1-T9). The number of years counted between match points is indicated. 


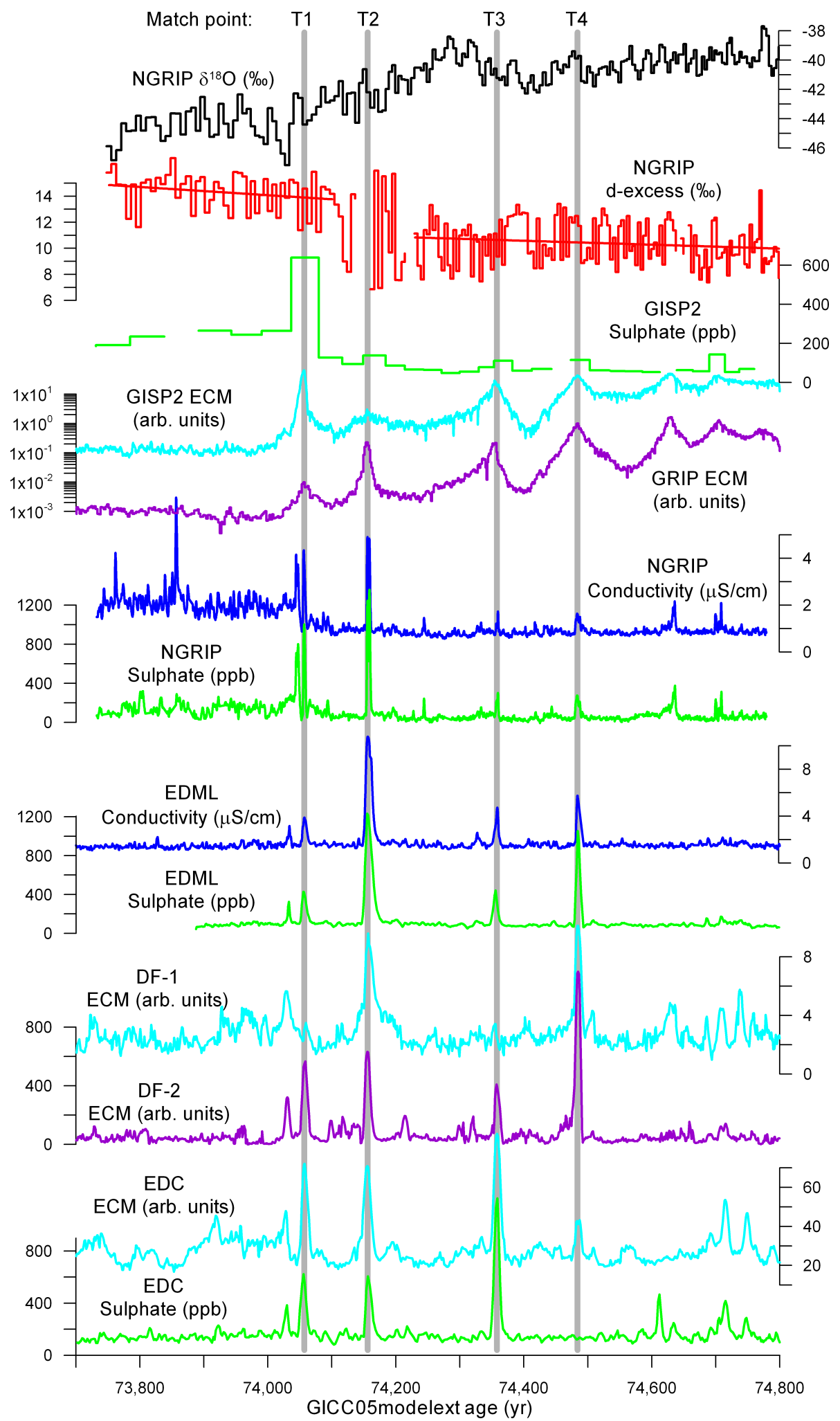

Fig. 8. Comparing volcanic ice core markers in Greenland (GISP2, GRIP, and NGRIP) and Antarctica (EDML, DF-1, DF-2, EDC) around the suggested Toba match covering the match points T1-T4. The upper curves show NGRIP $\delta{ }^{18} \mathrm{O}$ and deuterium excess (d-excess) including a piecewise linear fit (straight lines). DF-1 and DF-2 refers to Dome Fuji cores 1 and 2, respectively. GISP2 sulphate is from Zielinski et al. (1996) and GISP2 ECM is from Taylor et al. (1997). GRIP ECM is from Wolff et al. (1997) and DF-1 ECM is from Fujita et al. (2002). 
the last glacial (EPICA community members, 2006; Capron et al., 2010b; Pedro et al., 2011).

The phasing between the Greenland NGRIP and the Antarctic DF and EDC records reflects the classical imprint expected from an extended bipolar seesaw mechanism as described by Stocker and Johnsen (2003) very well, where an Atlantic temperature seesaw is connected to a large Southern Ocean heat reservoir (warming in Antarctica when Greenland is in a cold state connected to a lowered Atlantic Meridional Overturning Circulation (AMOC), and cooling in Antarctica when Greenland is warm and the AMOC is increased). The EDML ice core shows a somewhat different behaviour. In the EDML record we find a much faster warming at the onset of GS-21 and 20 which then tends to level out for the rest of these stadials. This pattern is also recognized for younger AIM during MIS3 (EPICA community members, 2006; Stenni et al., 2010). Taking the bipolar seesaw mechanism at face value, this would imply that the ocean heat pool relevant for the Atlantic sector of East Antarctica (EDML), which is warmed by the northward heat flux deficit across the Atlantic during the stadials, was much smaller than that relevant for the temperature response in the Indian Ocean sector (EDC). Since the Antarctic Circumpolar Current, however, is mixed rapidly within decades, this is highly unlikely and it appears difficult to maintain the required strong longitudinal temperature gradient in the Southern Ocean between the Atlantic and Indian Ocean sector. Accordingly, the Southern Ocean heat pool should be the same for both cases.

In contrast, the lower-latitude South Atlantic should respond much faster to changes in the northward heat transport by the AMOC and should be essentially in anti-phase according to the bipolar seesaw concept. While this may have an effect on the source temperature of the water vapour deposited at EDML, and thus on the deuterium excess, it should not have a strong effect on $\delta^{18} \mathrm{O}$ and the site temperature at EDML. In fact, the temperature record for the EDML site derived from $\delta^{18} \mathrm{O}$ after correction of source temperature effects using the deuterium excess (Stenni et al., 2010) shows essentially the same temporal behaviour during AIM as without correction, i.e. a relatively fast temperature increase at the onset of the AIM.

Accordingly, we need some other factor that can amplify the atmospheric warming signal in the $\delta^{18} \mathrm{O}$ record at the beginning of the AIM at EDML. This could potentially come about by a threshold in sea ice coverage and here especially in the extended summer sea ice coverage in the Atlantic sector during cold conditions. We speculate that a warming induced by the bipolar seesaw mechanism in the Atlantic sector of the Southern Ocean crosses such a threshold early during the AIM. A significantly reduced sea ice coverage then leads to a stronger atmospheric warming signal in this region. In fact, the EDML sodium record, which has been used as sea ice indicator, shows minima during the early stage of the AIM in MIS3 (Fischer et al., 2007a) pointing to quickly declining sea ice coverage at that time. In contrast, no such minima are observed in the EDC record (Fischer et al., 2007a). In this region of the Southern Ocean, summer sea ice was not significantly expanded even for peak glacial conditions (Gersonde et al., 2005) and thus no such threshold for the existence of summer sea ice exists. Accordingly, a somewhat different temporal evolution in the atmospheric temperature record of the EDML and EDC ice cores can be accommodated in the Bipolar Seesaw concept, if we take a sea ice amplification effect in the Atlantic sector into account.

\subsection{On the climatic impact of the Toba eruption(s)}

As pointed out in several studies (e.g. Zielinski, 2000), it is intriguing that the Toba event(s) occur(s) right at the time when the Greenland isotopes enter the lowest values of the entire glacial period (North Greenland Ice Core Project members, 2004). Also, in Chinese stalagmites the event corresponding to GS-20 is the isotopically most extreme event in this part of the last glacial period (Wang et al., 2008). However, it seems unlikely that a volcanic eruption should have initiated GS-20 when the initiation of other stadials and interstadials are thought not to be related to large volcanic eruptions. Still, there is the possibility that the eruption somehow contributed to make the GS-20 event a more extreme stadial period in the Northern Hemisphere, although it is difficult to imagine a mechanism that can sustain the extremely cold temperatures over more than a millennium.

In a global perspective, however, the Toba eruption did not initiate a long-term cold period (Fig. 9). In contrast, Antarctica experiences a major warming shortly after the Toba event(s). Concerning the possibility of volcano-related cooling events of less-than-a-century duration, it is more difficult to make a clear statement as the temporal resolution of the ice core water isotopes do not allow discussion of periods much shorter than that. Right after the T2 event an isotopic dip occurs in the EDML and DF ice cores lasting for about a century (Fig. 9). This event is potentially related to the T2 event, but we note that there are several other isotopic cooling events of similar amplitude occurring in EDML within AIM-20 that are unrelated to volcanic activity (Fig. 6). Based on the high-resolution ice core sulphate records, we know that the high sulphate concentrations associated with the bipolar volcanic events in this period last for about a decade. The volcanic sulphate aerosols are thus quickly removed from the atmosphere and any longer-term cooling impacted by volcanism must, therefore, be associated with feedback mechanisms that we cannot identify based on ice core records. A rather short-term climatic impact of the Toba eruption appears in good agreement with recent model simulations (Robock et al., 2009; Jones et al., 2005; Timmreck et al., 2012).

The inter-ice-core and inter-proxy variability in the magnitude of the identified Toba-related tie points is surprisingly high. In particular, the lack of coherence between GRIP and 


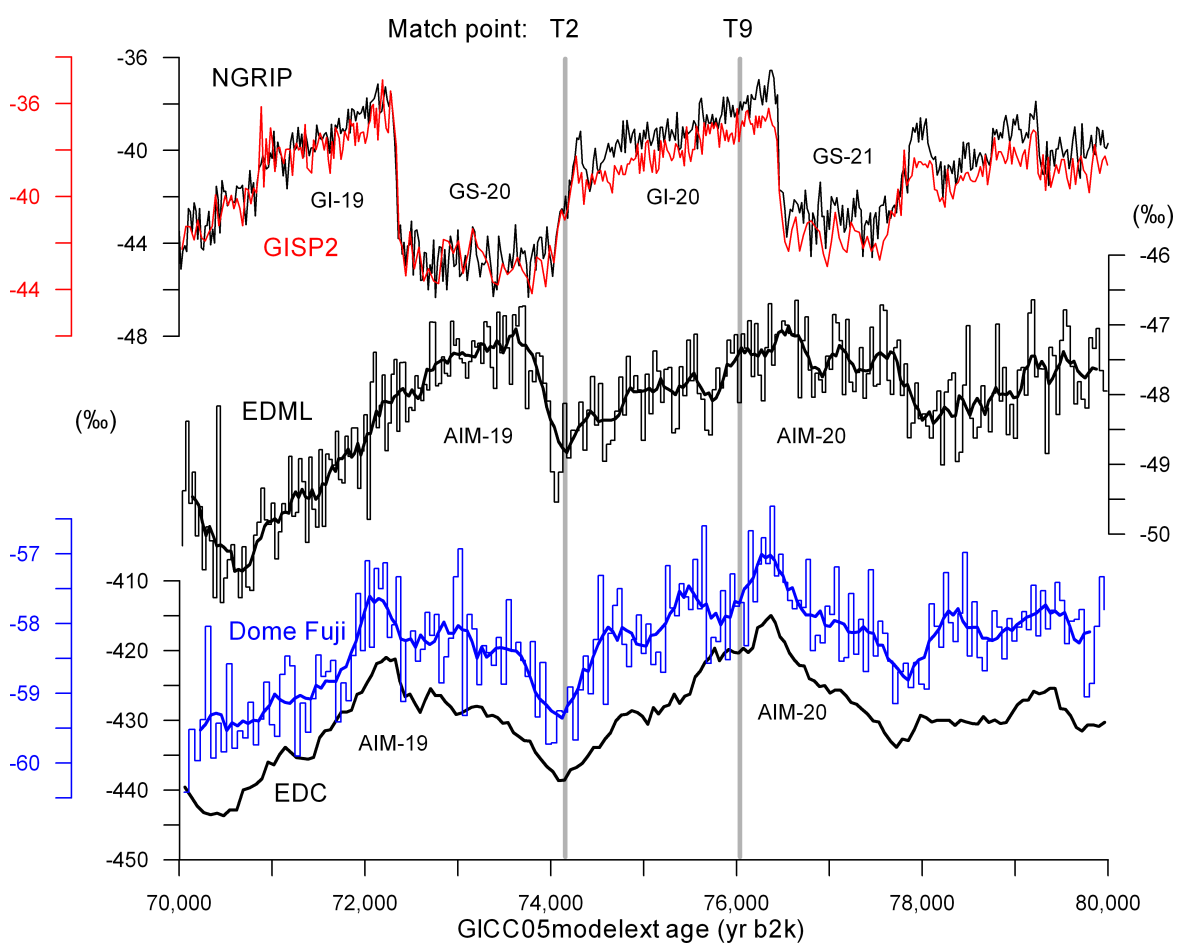

Fig. 9. Synchronization of the NGRIP (North Greenland Ice Core Project members, 2004), GISP2 (Grootes and Stuiver, 1997), EDML (EPICA community members, 2006), EDC (EPICA community members, 2004), and Dome Fuji 1 (Watanabe et al., 2003; Kawamura et al., 2007) isotopic profiles around GI-20 based on the Toba volcanic match. All records show $\delta^{18} \mathrm{O}$ except EDC, which is $\delta \mathrm{D}$. The EDML and EDC age models are modified from the Lemieux-Dudon et al. (2010) time scales that are shifted in time and linearly stretched by a few percent to fit the GICC05modelext ages of match points T2 and T9. The Dome Fuji age scale is treated in a similar way, but based on the time scale of Kawamura et al. (2007). For EDML and Dome Fuji, the thin step curve shows measured high-resolution isotopes, and the thick curves are running averages.

GISP2 at the T1 and T2 events is quite significant considering the sites are only located some $30 \mathrm{~km}$ apart. The strong variability suggests a substantial element of local variation in the magnitude of the volcanic signal during this period (Wolff et al., 2005).

In Greenland it is generally more challenging to use volcanic proxies, such as sulphate and conductivity, to identify volcanic events during cold climatic periods, such as glacial stadials. During cold periods the snow accumulation is low, the flux of dust and calcium sulphate (gypsum) to the ice increases dramatically (Iizuka et al., 2008), which in turn increase the sulphate and conductivity background levels (see Fig. 3). The occurrence of the $\mathrm{T} 1$ and $\mathrm{T} 2$ events right in the transition zone from the mild GI-20 to the cold GS-20 makes the peak heights very sensitive to the amount of dust in the ice, which can vary significantly from site to site on the annual and seasonal scale. This may explain part of the important difference between T1 and T2 at GRIP and GISP2. The issues described here do not apply to the warm and climatically stable Holocene, where the magnitude of volcanic eruptions is likely to carry a more quantitative signal. In general, however, it is recommended to compile as many ice core records as possible in quantitative studies following the approach of Gao et al. (2008).

\section{Conclusions}

By application of high-resolution impurity records from the Greenland NGRIP and the Antarctic EDML ice cores and by applying existing bipolar ice core synchronizations, it has been possible to obtain bipolar volcanic matches at the Laschamp geomagnetic excursion (ca. $41 \mathrm{kab} 2 \mathrm{k}$ ) and at the Toba mega-eruption (ca. $74 \mathrm{kab} 2 \mathrm{k}$ ).

Using constraints from precise Ar-Ar dating of Toba tephra and from precise U-Th dating of European stalagmites, we are certain that the Toba event occurs close to the onset of GS-20 in Greenland and between AIM-19 and AIM20 in Antarctica. The ice core records show evidence of four large bipolar eruptions occurring within four centuries close to the onset of GS-20. However, based on the ice core evidence alone we cannot determine how many of those events can be attributed to Toba. If there are several Toba eruptions within this time interval it may explain why none of the bipolar ice core events are as outstanding as would be expected from the geological evidence.

Our direct bipolar Toba synchronization gives very strong support for the bipolar seesaw hypothesis acting with no or little time lag in the MIS4/5 boundary region. At the EDML site in Dronning Maud Land, the climatic pattern differs 
somewhat from that of the East Antarctic Plateau suggesting that local effects such as sea ice cover may play an important role in that region.

Antarctic temperature proxies exclude the possibility of a more-than-a-century-long global cooling impact of the eruption(s) as Antarctica warms up shortly after the bipolar events. One of the ice core Toba candidates is potentially associated with a century-long Antarctic cooling episode, but the link is very uncertain. There are several other similarlooking Antarctic cooling episodes occurring in AIM-20 that are unrelated to volcanism. The high atmospheric sulphate loadings associated with the bipolar volcanic events are limited to about a decade, so any longer-term cooling must involve feedback mechanisms.

The approach taken here to synchronize Greenland and Antarctic ice cores by volcanic sequence matching has the potential to be expanded to other periods of the last glacial period.

\section{Supplementary material related to this article is available online at: http://www.clim-past.net/9/749/2013/ cp-9-749-2013-supplement.zip.}

Acknowledgements. This work is a contribution to the NGRIP ice core project, which is directed and organized by the Ice and Climate Research Group at the Niels Bohr Institute, University of Copenhagen. It is being supported by funding agencies in Denmark (SNF), Belgium (FNRS-CFB), France (IFRTP and INSU/CNRS), Germany (AWI), Iceland (RannIs), Japan (MEXT), Sweden (SPRS), Switzerland (SNF) and the United States of America (NSF).

This work is a contribution to the European Project for Ice Coring in Antarctica (EPICA), a joint European Science Foundation/European Commission scientific programme, funded by the EU and by national contributions from Belgium, Denmark, France, Germany, Italy, the Netherlands, Norway, Sweden, Switzerland and the United Kingdom. The main logistic support was provided by IPEV and PNRA (at Dome C) and AWI (at Dronning Maud Land). This is EPICA publication no. 289.

Edited by: E. Brook

\section{References}

Abbott, P. M., Davies, S. M., Steffensen, J. P., Pearce, N. J. G., Bigler, M., Johnsen, S. J., Seierstad, I. K., Svensson, A., and Wastegard, S.: A detailed framework of Marine Isotope Stages 4 and 5 volcanic events recorded in two Greenland ice-cores, Quaternary Sci. Rev., 36, 59-77, doi:10.1016/j.quascirev.2011.05.001, 2012.

Ambrose, S. H.: Late Pleistocene human population bottlenecks, volcanic winter, and differentiation of modern humans, J. Hum. Evol., 34, 623-651, doi:10.1006/jhev.1998.0219, 1998.
Andersen, K. K., Svensson, A., Rasmussen, S. O., Steffensen, J. P., Johnsen, S. J., Bigler, M., Röthlisberger, R., Ruth, U., SiggaardAndersen, M.-L., Dahl-Jensen, D., Vinther, B. M., and Clausen, H. B.: The Greenland Ice Core Chronology 2005, 15-42 ka. Part 1: constructing the time scale, Quaternary Sci. Rev., 25, 32463257, 2006.

Bay, R. C., Bramall, N. E., Price, P. B., Clow, G. D., Hawley, R. L., Udisti, R., and Castellano, E.: Globally synchronous ice core volcanic tracers and abrupt cooling during the last glacial period, J. Geophys. Res.-Atmos., 111, D11108, doi:10.1029/2005jd006306, 2006.

Bazin, L., Landais, A., Lemieux-Dudon, B., Toyé Mahamadou Kele, H., Veres, D., Parrenin, F., Martinerie, P., Ritz, C., Capron, E., Lipenkov, V., Loutre, M.-F., Raynaud, D., Vinther, B., Svensson, A., Rasmussen, S. O., Severi, M., Blunier, T., Leuenberger, M., Fischer, H., Masson-Delmotte, V., Chappellaz, J., and Wolff, E.: An optimized multi-proxy, multi-site Antarctic ice and gas orbital chronology (AICC2012): 120-800 ka, Clim. Past Discuss., 8, 5963-6009, doi:10.5194/cpd-8-5963-2012, 2012.

Bender, M., Sowers, T., Dickson, M.-L., Orchardo, J., Grootes, P., Mayewski, P. A., and Meese, D. A.: Climate correlations between Greenland and Antarctica during the last 100,000 years, Nature, 372, 663-666, 1994.

Bigler, M.: Hochauflösende Spurenstoffmessungen an polaren Eisbohrkernen: Glazio-chemische und klimatische Prozessstudien, Physics Institute, University of Bern, Switzerland, 2004.

Blockley, S. P. E., Lane, C. S., Hardiman, M., Rasmussen, S. O., Seierstad, I. K., Steffensen, J. P., Svensson, A., Lotter, A. F., Turney, C. S. M., and Ramsey, C. B.: Synchronisation of palaeoenvironmental records over the last 60,000 years, and an extended INTIMATE(1) event stratigraphy to 48,000 b2k, Quaternary Sci. Rev., 36, 2-10, doi:10.1016/j.quascirev.2011.09.017, 2012.

Blunier, T. and Brook, E. J.: Timing of millennial-scale climate change in Antarctica and Greenland during the last glacial period, Science, 291, 109-112, 2001.

Blunier, T., Chappellaz, J., Schwander, J., Dällenbach, A., Stauffer, B., Stocker, T. F., Raynaud, D., Jouzel, J., Clausen, H. B., Hammer, C. U., and Johnsen, S. J.: Asynchrony of Antarctic and Greenland climate change during the last glacial period, Nature, 394, 739-743, 1998.

Blunier, T., Spahni, R., Barnola, J.-M., Chappellaz, J., Loulergue, L., and Schwander, J.: Synchronization of ice core records via atmospheric gases, Clim. Past, 3, 325-330, doi:10.5194/cp-3-3252007, 2007.

Boch, R., Cheng, H., Spötl, C., Edwards, R. L., Wang, X., and Häuselmann, Ph.: NALPS: a precisely dated European climate record 120-60 ka, Clim. Past, 7, 1247-1259, doi:10.5194/cp-71247-2011, 2011.

Broecker, W. S.: Paleocean circulation during the last deglaciation: A bipolar seesaw?, Paleoceanography, 13, 119-121, 1998.

Buizert, C., Martinerie, P., Petrenko, V. V., Severinghaus, J. P., Trudinger, C. M., Witrant, E., Rosen, J. L., Orsi, A. J., Rubino, M., Etheridge, D. M., Steele, L. P., Hogan, C., Laube, J. C., Sturges, W. T., Levchenko, V. A., Smith, A. M., Levin, I., Conway, T. J., Dlugokencky, E. J., Lang, P. M., Kawamura, K., Jenk, T. M., White, J. W. C., Sowers, T., Schwander, J., and Blunier, T. Gas transport in firn: multiple-tracer characterisation and model intercomparison for NEEM, Northern Greenland, Atmos. Chem. Phys., 12, 4259-4277, doi:10.5194/acp-12-4259-2012, 2012. 
Capron, E., Landais, A., Chappellaz, J., Schilt, A., Buiron, D., Dahl-Jensen, D., Johnsen, S. J., Jouzel, J., Lemieux-Dudon, B., Loulergue, L., Leuenberger, M., Masson-Delmotte, V., Meyer, H., Oerter, H., and Stenni, B.: Millennial and sub-millennial scale climatic variations recorded in polar ice cores over the last glacial period, Clim. Past, 6, 345-365, doi:10.5194/cp-6-3452010, 2010a.

Capron, E., Landais, A., Lemieux-Dudon, B., Schilt, A., MassonDelmotte, V., Buiron, D., Chappellaz, J., Dahl-Jensen, D., Johnsen, S., Leuenberger, M., Loulergue, L., and Oerter, H.: Synchronising EDML and NorthGRIP ice cores using $\delta^{18} \mathrm{O}$ of atmospheric oxygen $\left(\delta^{18} \mathrm{O}_{\mathrm{atm}}\right)$ and $\mathrm{CH}_{4}$ measurements over MIS5 (80-123 kyr), Quaternary Sci. Rev., 29, 222-234, doi:10.1016/j.quascirev.2009.07.014, 2010b.

Cavitte, M. G. P., Blankenship, D. D., Young, D. A., Siegert, M. J., and Le Meur, E.: Radar stratigraphy connecting Lake Vostok and Dome C, East Antarctica, constrains the EPICA/DMC ice core time scale, The Cryosphere Discuss., 7, 321-342, doi:10.5194/tcd-7-321-2013, 2013.

Chesner, C. A.: The Toba Caldera Complex, Quaternary Int., 258, 5-18, doi:10.1016/j.quaint.2011.09.025, 2012.

Chesner, C. A. and Luhr, J. F.: A melt inclusion study of the Toba Tuffs, Sumatra, Indonesia, J. Volcanol. Geoth. Res., 197, 259278, doi:10.1016/j.jvolgeores.2010.06.001, 2010.

Chesner, C. A., Rose, W. I., Deino, A., Drake, R., and Westgate, J. A.: Eruptive history of Earth's Largest Quaternary Caldera (Toba, Indonesia) clarified, Geology, 19, 200-203, 1991.

Clausen, H. B., Hammer, C. U., Hvidberg, C. S., Dahl-Jensen, D., Steffensen, J. P., Kipfstuhl, J., and Legrand, M.: A comparison of the volcanic records over the past 4000 years from the Greenland Ice Core Project and Dye 3 Greenland ice cores, J. Geophys. Res., 102, 26707-26723, 1997.

Dahl-Jensen, D., Gundestrup, N., Miller, H., Watanabe, O., Johnsen, S. J., Steffensen, J. P., Clausen, H. B., Svensson, A., and Larsen, L. B.: The NorthGRIP deep drilling program, Ann. Glaciol., 35, $1-4,2002$.

Dansgaard, W., Johnsen, S. J., Clausen, H. B., Dahl-Jensen, D., Gundestrup, N. S., Hammer, C. U., Hvidberg, C. S., Steffensen, J. P., Sveinbjörnsdottir, A. E., Jouzel, J., and Bond, G.: Evidence for general instability of past climate from a $250-\mathrm{kyr}$ ice-core record, Nature, 364, 218-220, 1993.

Ellis, B. S., Mark, D. F., Pritchard, C. J., and Wolff, J. A.: Temporal dissection of the Huckleberry Ridge Tuff using the Ar-40/Ar-39 dating technique, Quat. Geochronol., 9, 34-41, doi:10.1016/j.quageo.2012.01.006, 2012.

EPICA community members: Eight glacial cycles from an Antarctic ice core, Nature, 429, 623-628, 2004.

EPICA community members: One-to-one coupling of glacial climate variability in Greeland and Antartctica, Nature, 444, 195198, 2006.

Faria, S. H., Freitag, J., and Kipfstuhl, S.: Polar ice structure and the integrity of ice-core paleoclimate records, Quaternary Sci. Rev., 29, 338-351, doi:10.1016/j.quascirev.2009.10.016, 2010.

Fischer, H., Fundel, F., Ruth, U., Twarloh, B., Wegner, A., Udisti, R., Becagli, S., Castellano, E., Morganti, A., Severi, M., Wolff, E., Littot, G., Röthlisberger, R., Mulvaney, R., Hutterlid, M. A., Kaufmann, P., Federer, U., Lambert, F., Bigler, M., Hansson, M., Jonsell, U., Angelis, M. D., Boutron, C., Siggaard-Andersen, M.L., Steffensen, J. P., Barbante, C., Gaspari, V., Gabrielli, P., and
Wagenbach, D.: Reconstruction of millennial changes in dust emission, transport and regional sea ice coverage using the deep EPICA ice cores from the Atlantic and Indian Ocean sector of Antarctica, Earth Planet. Sc. Lett., 260, 340-354, 2007a.

Fischer, H., Siggaard-Andersen, M.-L., Ruth, U., Röthlisberger, R., and Wolff, E.: Glacial/interglacial changes in mineral dust and sea-salt records in polar ice cores: Sources, transport, and deposition, Rev. Geophys., 45, RG1002, doi:1010.1029/2005RG000192, 2007b.

Fujita, S., Azuma, N., Motoyama, H., Kameda, T., Narita, H., Fujii, Y., and Watanabe, O.: Electrical measurements on the $2503 \mathrm{~m}$ Dome F Antarctic ice core, Ann. Glaciol., 35, 313-320, 2002.

Fujita, S., Holmlund, P., Matsuoka, K., Enomoto, H., Fukui, K., Nakazawa, F., Sugiyama, S., and Surdyk, S.: Radar diagnosis of the subglacial conditions in Dronning Maud Land, East Antarctica, The Cryosphere, 6, 1203-1219, doi:10.5194/tc-61203-2012, 2012.

Gao, C. C., Robock, A., and Ammann, C.: Volcanic forcing of climate over the past 1500 years: An improved ice core-based index for climate models, J. Geophys. Res.-Atmos., 113, D23111, doi:10.1029/2008jd010239, 2008.

Gersonde, R., Crosta, X., Abelmann, A., and Armand, L.: Seasurface temperature and sea ice distribution of the Southern Ocean at the EPILOG Last Glacial Maximum - a circumAntarctic view based on siliceous microfossil records, Quaternary Sci. Rev., 24, 869-896, 2005.

Goujon, C., Barnola, J.-M., and Ritz, C.: Modeling the densification of polar firn including heat diffusion: Application to close-off characteristics and gas isotopic fractionation for Antarctica and Greenland sites, J. Geophys. Res., 108, 4792, doi:4710.1029/2002JD003319, 2003.

Grootes, P. M. and Stuiver, M.: Oxygen 18/16 variability in Greenland snow and ice with $10^{-3}$ - to $10^{5}$-year time resolution, J. Geophys. Res., 102, 26455-26470, 1997.

Haslam, M. and Petraglia, M.: Comment on "Environmental impact of the $73 \mathrm{ka}$ Toba super-eruption in South Asia" by Williams,M. A. J., Ambrose, S. H., van der Kaars, S., Ruehlemann, C., Chattopadhyaya, U., Pal, J., and Chauhan, P. R., Palaeogeogr. Palaeocl., 296, 199-203, doi:10.1016/j.palaeo.2010.03.057, 2010.

Hörhold, M. W., Laepple, T., Freitag, J., Bigler, M., Fischer, H., and Kipfstuhl, S.: On the impact of impurities on the densification of polar firn, Earth Planet. Sc. Lett., 325, 93-99, doi:10.1016/j.epsl.2011.12.022, 2012.

Huang, C. Y., Zhao, M. X., Wang, C. C., and Wei, G. J.: Cooling of the South China Sea by the Toba eruption and correlation with other climate proxies similar to 71,000 years ago, Geophys. Res. Lett., 28, 3915-3918, doi:10.1029/2000g1006113, 2001.

Iizuka, Y., Horikawa, S., Sakurai, T., Johnson, S., Dahl-Jensen, D., Steffensen, J. P., and Hondoh, T.: A relationship between ion balance and the chemical compounds of salt inclusions found in the Greenland Ice Core Project and Dome Fuji ice cores, J. Geophys. Res.-Atmos., 113, doi:10.1029/2007jd009018, 2008.

Jones, G. S., Gregory, J. M., Stott, P. A., Tett, S. F. B., and Thorpe, R. B.: An AOGCM simulation of the climate response to a volcanic super-eruption, Clim. Dynam., 25, 725-738, doi:10.1007/s00382-005-0066-8, 2005.

Jouzel, J., Masson-Delmotte, V., Cattani, O., Dreyfus, G., Falourd, S., Hoffmann, G., Minster, B., Nouet, J., Barnola, J. M., Chap- 
pellaz, J., Fischer, H., Gallet, J. C., Johnsen, S., Leuenberger, M., Loulergue, L., Luethi, D., Oerter, H., Parrenin, F., Raisbeck, G., Raynaud, D., Schilt, A., Schwander, J., Selmo, E., Souchez, R., Spahni, R., Stauffer, B., Steffensen, J. P., Stenni, B., Stocker, T. F., Tison, J. L., Werner, M., and Wolff, E. W.: Orbital and millennial Antarctic climate variability over the past 800,000 years, Science, 317, 793-796, doi:10.1126/science.1141038, 2007.

Kaufmann, P., Fundel, F., Fischer, H., Bigler, M., Ruth, U., Udisti, R., Hansson, M., de Angelis, M., Barbante, C., Wolff, E. W., Hutterli, M., and Wagenbach, D.: Ammonium and non-sea salt sulfate in the EPICA ice cores as indicator of biological activity in the Southern Ocean, Quaternary Sci. Rev., 29, 313-323, doi:10.1016/j.quascirev.2009.11.009, 2010.

Kawamura, K., Parrenin, F., Lisiecki, L., Uemura, R., Vimeux, F., Severinghaus, J. P., Hutterli, M. A., Nakazawa, T., Aoki, S., Jouzel, J., Raymo, M. E., Matsumoto, K., Nakata, H., Motoyama, H., Fujita, S., Goto-Azuma, K., Fujii, Y., and Watanabe, O.: Northern Hemisphere forcing of climatic cycles in Antarctica over the past 360,000 years, Nature, 448, 912-914, doi:10.1038/nature06015, 2007.

Kudrass, H. R., Hofmann, A., Doose, H., Emeis, K., and Erlenkeuser, H.: Modulation and amplification of climatic changes in the Northern Hemisphere by the Indian summer monsoon during the past $80 \mathrm{k} . \mathrm{y}$, Geology, 29, 63-66, 2001.

Lane, C., Haslam, M., Petraglia, M., Ditchfield, P., Smith, V., and Korisettar, R.: Cryptotephra from the $74 \mathrm{ka} \mathrm{BP}$ Toba supereruption in the Billa Surgam caves, southern India, Quaternary Sci. Rev., 30, 1819-1824, doi:10.1016/j.quascirev.2011.05.010, 2011.

Lemieux-Dudon, B., Blayo, E., Petit, J. R., Waelbroeck, C., Svensson, A., Ritz, C., Barnola, J. M., Narcisi, B. M., and Parrenin, F.: Consistent dating for Antarctic and Greenland ice cores, Quaternary Sci. Rev., 29, 8-20, doi:10.1016/j.quascirev.2009.11.010, 2010.

Loulergue, L., Parrenin, F., Blunier, T., Barnola, J.-M., Spahni, R., Schilt, A., Raisbeck, G., and Chappellaz, J.: New constraints on the gas age-ice age difference along the EPICA ice cores, 0-50 kyr, Clim. Past, 3, 527-540, doi:10.5194/cp-3-527-2007, 2007.

Louys, J.: Mammal community structure of Sundanese fossil assemblages from the Late Pleistocene, and a discussion on the ecological effects of the Toba eruption, Quaternary Int., 258, 8087, doi:10.1016/j.quaint.2011.07.027, 2012.

Mark, D. F., Petraglia, M., Smith, V. C., Morgan, L. E., Barfod, D. N., Ellis, B. S., Pearce, N. J., Pal, J. N., and Korisettar, R.: A high-precision 40Ar/39Ar age for the Young Toba Tuff and dating of ultra-distal tephra: forcing of Quaternary climate and implications for hominin occupation of India, Quat. Geochronol., online first, doi:10.1016/j.quageo.2012.12.004, 2013.

Mayewski, P. A., Meeker, L. D., Twickler, M. S., Whitlow, S., Yang, Q. Z., Lyons, W. B., and Prentice, M.: Major features and forcing of high-latitude northern hemisphere atmospheric circulation using a 110,000-year-long glaciochemical series, J. Geophys. Res.Ocean, 102, 26345-26366, 1997.

North Greenland Ice Core Project members: High-resolution record of Northern Hemisphere climate extending into the last interglacial period, Nature, 431, 147-151, 2004.

Oppenheimer, C.: Limited global change due to the largest known Quaternary eruption, Toba approximate to $74 \mathrm{kyr} \mathrm{BP}$ ?,
Quaternary Sci. Rev., 21, 1593-1609, doi:10.1016/s02773791(01)00154-8, 2002.

Parrenin, F., Barnola, J.-M., Beer, J., Blunier, T., Castellano, E., Chappellaz, J., Dreyfus, G., Fischer, H., Fujita, S., Jouzel, J., Kawamura, K., Lemieux-Dudon, B., Loulergue, L., MassonDelmotte, V., Narcisi, B., Petit, J.-R., Raisbeck, G., Raynaud, D., Ruth, U., Schwander, J., Severi, M., Spahni, R., Steffensen, J. P., Svensson, A., Udisti, R., Waelbroeck, C., and Wolff, E.: The EDC3 chronology for the EPICA Dome C ice core, Clim. Past, 3, 485-497, doi:10.5194/cp-3-485-2007, 2007.

Parrenin, F., Petit, J.-R., Masson-Delmotte, V., Wolff, E., BasileDoelsch, I., Jouzel, J., Lipenkov, V., Rasmussen, S. O., Schwander, J., Severi, M., Udisti, R., Veres, D., and Vinther, B. M.: Volcanic synchronisation between the EPICA Dome $\mathrm{C}$ and Vostok ice cores (Antarctica) 0-145 kyr BP, Clim. Past, 8, 1031-1045, doi:10.5194/cp-8-1031-2012, 2012.

Pedro, J. B., van Ommen, T. D., Rasmussen, S. O., Morgan, V. I., Chappellaz, J., Moy, A. D., Masson-Delmotte, V., and Delmotte, M.: The last deglaciation: timing the bipolar seesaw, Clim. Past, 7, 671-683, doi:10.5194/cp-7-671-2011, 2011.

Petraglia, M., Korisettar, R., Boivin, N., Clarkson, C., Ditchfield, P., Jones, S., Koshy, J., Lahr, M. M., Oppenheimer, C., Pyle, D., Roberts, R., Schwenninger, J. L., Arnold, L., and White, K.: Middle paleolithic assemblages from the Indian subcontinent before and after the Toba super-eruption, Science, 317, 114-116, doi:10.1126/science.1141564, 2007.

Raisbeck, G. M., Yiou, F., Jouzel, J., and Stocker, T. F.: Direct north-south synchronization of abrupt climate change record in ice cores using Beryllium 10, Clim. Past, 3, 541-547, doi:10.5194/cp-3-541-2007, 2007.

Rampino, M. R. and Self, S.: Volcanic winter and accelerated glaciation following the Toba super-eruption, Nature, 359, 5052, 1992.

Rasmussen, M., Guo, X. S., Wang, Y., Lohmueller, K. E., Rasmussen, S., Albrechtsen, A., Skotte, L., Lindgreen, S., Metspalu, M., Jombart, T., Kivisild, T., Zhai, W. W., Eriksson, A., Manica, A., Orlando, L., De La Vega, F. M., Tridico, S., Metspalu, E., Nielsen, K., Avila-Arcos, M. C., Moreno-Mayar, J. V., Muller, C., Dortch, J., Gilbert, M. T. P., Lund, O., Wesolowska, A., Karmin, M., Weinert, L. A., Wang, B., Li, J., Tai, S. S., Xiao, F., Hanihara, T., van Driem, G., Jha, A. R., Ricaut, F. X., de Knijff, P., Migliano, A. B., Romero, I. G., Kristiansen, K., Lambert, D. M., Brunak, S., Forster, P., Brinkmann, B., Nehlich, O., Bunce, M., Richards, M., Gupta, R., Bustamante, C. D., Krogh, A., Foley, R. A., Lahr, M. M., Balloux, F., Sicheritz-Ponten, T., Villems, R., Nielsen, R., Wang, J., and Willerslev, E.: An Aboriginal Australian Genome Reveals Separate Human Dispersals into Asia, Science, 333, 94-98, doi:10.1126/science.1211177, 2011.

Rasmussen, S. O., Andersen, K. K., Svensson, A. M., Steffensen, J. P., Vinther, B. M., Clausen, H. B., Siggaard-Andersen, M.L., Johnsen, S. J., Larsen, L. B., Dahl-Jensen, D., Bigler, M., Röthlisberger, R., Fischer, H., Goto-Azuma, K., Hansson, M. E., and Ruth, U.: A new Greenland ice core chronology for the last glacial termination, J. Geophys. Res., 111, D06102, doi:10.1029/2005JD006079, 2006.

Rasmussen, S. O., Seierstad, I. K., Andersen, K. K., Bigler, M., Dahl-Jensen, D., and Johnsen, S. J.: Synchronization of the NGRIP, GRIP, and GISP2 ice cores across MIS 2 and palaeoclimatic implications, Quaternary Sci. Rev., 27, 18-28, 
doi:10.1016/j.quascirev.2007.01.016, 2008.

Robock, A.: Volcanic eruptions and climate, Rev. Geophys., 38, 191-219, 2000.

Robock, A., Ammann, C. M., Oman, L., Shindell, D., Levis, S., and Stenchikov, G.: Did the Toba volcanic eruption of similar to $74 \mathrm{ka} \mathrm{BP}$ produce widespread glaciation?, J. Geophys. Res.Atmos., 114, D10107, doi:10.1029/2008jd011652, 2009.

Ruth, U., Wagenbach, D., Steffensen, J. P., and Bigler, M.: Continuous record of microparticle concentration and size distribution in the central Greenland NGRIP ice core during the last glacial period, J. Geophys. Res., 108, 4098, doi:4010.1029/2002JD002376, 2003.

Ruth, U., Barnola, J.-M., Beer, J., Bigler, M., Blunier, T., Castellano, E., Fischer, H., Fundel, F., Huybrechts, P., Kaufmann, P., Kipfstuhl, S., Lambrecht, A., Morganti, A., Oerter, H., Parrenin, F., Rybak, O., Severi, M., Udisti, R., Wilhelms, F., and Wolff, E.: "EDML1": a chronology for the EPICA deep ice core from Dronning Maud Land, Antarctica, over the last 150000 years, Clim. Past, 3, 475-484, doi:10.5194/cp-3-475-2007, 2007.

Schulz, H., von Rad, U., and Erlenkeuser, H.: Correlation between Arabian sea and Greenland climate oscillation of the past 110,000 years, Nature, 393, 54-57, 1998.

Schulz, H., Emeis, K. C., Erlenkeuser, H., von Rad, U., and Rolf, C.: The Toba volcanic event and interstadial/stadial climates at the marine isotopic stage 5 to 4 transition in the northern Indian Ocean, Quaternary Res., 57, 22-31, doi:10.1006/qres.2001.2291, 2002.

Schwander, J., Barnola, J.-M., Andrié, C., Leuenberger, M., Ludin, A., Raynaud, D., and Stauffer, B.: The age of the air in the firn and the ice at Summit, Greenland, J. Geophys. Res., 98, 28312838, 1993.

Severi, M., Becagli, S., Castellano, E., Morganti, A., Traversi, R., Udisti, R., Ruth, U., Fischer, H., Huybrechts, P., Wolff, E., Parrenin, F., Kaufmann, P., Lambert, F., and Steffensen, J. P.: Synchronisation of the EDML and EDC ice cores for the last $52 \mathrm{kyr}$ by volcanic signature matching, Clim. Past, 3, 367-374, doi:10.5194/cp-3-367-2007, 2007.

Sigl, M., McConnell, J. R., Layman, L., Maselli, O., McGwire, K., Pasteris, D., Dahl-Jensen, D., Steffensen, J. P., Vinther, B., Edwards, R., Mulvaney, R., and Kipfstuhl, S.: A new bipolar ice core record of volcanism from WAIS Divide and NEEM and implications for climate forcing of the last 2000 years, J. Geophys. Res.-Atmos., online first, doi:10.1029/2012JD018603, 2012.

Singer, B. S., Guillou, H., Jicha, B. R., Laj, C., Kissel, C., Beard, B. L., and Johnson, C. M.: Ar-40/Ar-39, K-Ar and Th-230-U-238 dating of the Laschamp excursion: A radioisotopic tie-point for ice core and climate chronologies, Earth Planet. Sc. Lett., 286, 80-88, doi:10.1016/j.eps1.2009.06.030, 2009.

Steffensen, J. P., Andersen, K. K., Bigler, M., Clausen, H. B., DahlJensen, D., Fischer, H., Goto-Azuma, K., Hansson, M., Johnsen, S. J., Jouzel, J., Masson-Delmotte, V., Popp, T., Rasmussen, S. O., Röthlisberger, R., Ruth, U., Stauffer, B., Siggaard-Andersen, M.-L., Sveinbjörnsdóttir, Á. E., Svensson, A., and White, J. W. C.: High-resolution Greenland ice core data show abrupt climate change happens in few years, Science, 321, 680-684, 2008.

Stenni, B., Buiron, D., Frezzotti, M., Albani, S., Barbante, C., Bard, E., Barnola, J. M., Baroni, M., Baumgartner, M., Bonazza, M., Capron, E., Castellano, E., Chappellaz, J., Delmonte, B., Falourd, S., Genoni, L., Iacumin, P., Jouzel, J., Kipfstuhl, S., Landais,
A., Lemieux-Dudon, B., Maggi, V., Masson-Delmotte, V., Mazzola, C., Minster, B., Montagnat, M., Mulvaney, R., Narcisi, B., Oerter, H., Parrenin, F., Petit, J. R., Ritz, C., Scarchilli, C., Schilt, A., Schupbach, S., Schwander, J., Selmo, E., Severi, M., Stocker, T. F., and Udisti, R.: Expression of the bipolar see-saw in Antarctic climate records during the last deglaciation, Nat. Geosci., 4, 46-49, doi:10.1038/ngeo1026, 2010.

Stocker, T. F. and Johnsen, S. J.: A minimum thermodynamic model for the bipolar seesaw, Paleoceanography, 18, 1087, doi:1010.1029/2003PA000920, 2003.

Storey, M., Roberts, R. G., and Saidin, M.: Astronomically calibrated Ar-40/Ar-39 age for the Toba supereruption and global synchronization of late Quaternary records, P. Natl. Acad. Sci USA, 109, 18684-18688, doi:10.1073/pnas.1208178109, 2012.

Svensson, A., Nielsen, S. W., Kipfstuhl, S., Johnsen, S. J., Steffensen, J. P., Bigler, M., Ruth, U., and Röthlisberger, R.: Visual stratigraphy of the North Greenland Ice Core Project (NorthGRIP) ice core during the last glacial period, J. Geophys. Res., 110, D02108, doi:02110.01029/02004JD005134, 2005.

Svensson, A., Andersen, K. K., Bigler, M., Clausen, H. B., DahlJensen, D., Davies, S. M., Johnsen, S. J., Muscheler, R., Parrenin, F., Rasmussen, S. O., Röthlisberger, R., Seierstad, I., Steffensen, J. P., and Vinther, B. M.: A 60000 year Greenland stratigraphic ice core chronology, Clim. Past, 4, 47-57, doi:10.5194/cp-4-472008, 2008.

Taylor, K. C., Alley, R. B., Lamorey, G. W., and Mayewski, P.: Electrical measurements on the Greenland Ice Sheet Project 2 Core, J. Geophys. Res., 102, 26511-26517, 1997.

Timmreck, C., Graf, H. F., Zanchettin, D., Hagemann, S., Kleinen, T., and Kruger, K.: Climate response to the Toba super-eruption: Regional changes, Quaternary Int., 258, 30-44, doi:10.1016/j.quaint.2011.10.008, 2012.

Udisti, R., Becagli, S., Castellano, E., Delmonte, B., Jouzel, J., Petit, J. R., Schwander, J., Stenni, B., and Wolff, E. W.: Stratigraphic correlations between the European Project for Ice Coring in Antarctica (EPICA) Dome C and Vostok ice cores showing the relative variations of snow accumulation over the past $45 \mathrm{kyr}$, J. Geophys. Res., 109, D08101, doi:08110.01029/02003JD004180, 2004.

Vallelonga, P., Bertagna, G., Blunier, T., Kjær, H. A., Popp, T. J., Rasmussen, S. O., Steffensen, J. P., Stowasser, C., Svensson, A. S., Warming, E., Winstrup, M., Bigler, M., and Kipfstuhl, S.: Duration of Greenland Stadial 22 and ice-gas $\Delta$ age from counting of annual layers in Greenland NGRIP ice core, Clim. Past, 8, 1839-1847, doi:10.5194/cp-8-1839-2012, 2012.

Veres, D., Bazin, L., Landais, A., Toyé Mahamadou Kele, H., Lemieux-Dudon, B., Parrenin, F., Martinerie, P., Blayo, E., Blunier, T., Capron, E., Chappellaz, J., Rasmussen, S. O., Severi, M., Svensson, A., Vinther, B., and Wolff, E. W.: The Antarctic ice core chronology (AICC2012): an optimized multi-parameter and multi-site dating approach for the last 120 thousand years, Clim. Past Discuss., 8, 6011-6049, doi:10.5194/cpd-8-60112012, 2012.

Vinther, B. M., Clausen, H. B., Johnsen, S. J., Rasmussen, S. O., Andersen, K. K., Buchardt, S. L., Dahl-Jensen, D., Seierstad, I. K., Siggaard-Andersen, M.-L., Steffensen, J. P., Svensson, A. M., Olsen, J., and Heinemeier, J.: A synchronized dating of three Greenland ice cores throughout the Holocene, J. Geophys. Res., 111, D13102, doi:13110.11029/12005JD006921, 2006. 
Vinther, B. M., Clausen, H. B., Kipfstuhl, S., Fischer, H., Bigler, M., Oerter, H., Wegner, A., Wilhelms, F., Severi, M., Udisti, R., Beer, J., Steinhilber, F., Muscheler, R., Rasmussen, S. O., and Svensson, A.: An annual layer counted EDML time scale covering the past 16700 years, Geophys. Res. Abstr., EGU2012-13043, EGU General Assembly 212, Vienna, Austria, 2012.

Wang, Y. J., Cheng, H., Edwards, R. L., Kong, X. G., Shao, X. H., Chen, S. T., Wu, J. Y., Jiang, X. Y., Wang, X. F., and An, Z. S.: Millennial- and orbital-scale changes in the East Asian monsoon over the past 224,000 years, Nature, 451, 1090-1093, doi:10.1038/nature06692, 2008.

Watanabe, O., Jouzel, J., Johnsen, S., Parrenin, F., Shoji, H., and Yoshida, N.: Homogeneous climate variability across East Antarctica over the past three glacial cycles, Nature, 422, 509512, doi:10.1038/nature01525, 2003.

Westaway, R., Mishra, S., Deo, S., and Bridgland, D. R.: Methods for determination of the age of Pleistocene tephra, derived from eruption of Toba, in central India, J. Earth Syst. Sci., 120, 503530, doi:10.1007/s12040-011-0087-0, 2011.

Westgate, J. A., Shane, P. A. R., Pearce, N. J. G., Perkins, W. T., Korisettar, R., Chesner, C. A., Williams, M. A. J., and Acharyya, S. K.: All Toba tephra occurrences across peninsular India belong to the 75,000 yr BP eruption, Quaternary Res. 50, 107-112, doi:10.1006/qres.1998.1974, 1998.

Wilhelms, F., Kipfstuhl, J., Miller, H., Heinloth, K., and Firestone, J.: Precise dielectric profiling of ice cores: a new device with improved guarding and its theory, J. Glaciol., 44, 171-174, 1998.

Williams, M.: The similar to $73 \mathrm{ka}$ Toba super-eruption and its impact: History of a debate, Quaternary Int., 258, 19-29, doi:10.1016/j.quaint.2011.08.025, 2012.
Wolff, E. W., Moore, J. C., Clausen, H. B., and Hammer, C. U.: Climatic implications of background acidity and other chemistry derived from electrical studies of the Greenland Ice Core Project ice core, J. Geophys. Res., 102, 26325-26332, 1997.

Wolff, E. W., Cook, E., Barnes, P. R. F., and Mulvaney, R.: Signal variability in replicate ice cores, J. Glaciol., 51, 462-468, 2005.

Wolff, E. W., Chappellaz, J., Blunier, T., Rasmussen, S. O., and Svensson, A.: Millennial-scale variability during the last glacial: The ice core record, Quaternary Sci. Rev., 29, 2828-2838, doi:10.1016/j.quascirev.2009.10.013, 2010.

Yang, Q., Mayewski, P. A., Zielinski, G. A., Twickler, M., and Taylor, K. C.: Depletion of atmospheric nitrate and chloride as a consequence of the Toba volcanic eruption, Geophys. Res. Lett., 23 , 2513-2516, doi:10.1029/96g102201, 1996.

Yiou, F., Raisbeck, G. M., Baumgartner, S., Beer, J., Hammer, C., Johnsen, S., Jouzel, J., Kubik, P. W., Lestringuez, J., Stiévenard, M., Suter, M., and Yiou, P.: Beryllium 10 in Greenland Ice Core Project ice core at Summit, Greenland, J. Geophys. Res., 102, 26783-26794, 1997.

Zielinski, G. A.: Use of paleo-records in determining variability within the volcanism-climate system, Quaternary Sci. Rev., 19, 417-438, 2000.

Zielinski, G. A., Mayewski, P. A., Meeker, L. D., Whitlow, S., Twickler, M. S., and Taylor, K.: Potential atmospheric impact of the Toba mega-eruption $\sim 71,000$ years ago, Geophys. Res. Lett., 23, 837-840, 1996. 